University of Nebraska - Lincoln

DigitalCommons@University of Nebraska - Lincoln

Textile Society of America Symposium

Proceedings

Textile Society of America

2020

\title{
India in Situ: Textile History and Practice, a Team Approach
}

Annin Barrett

anninbarrett.com, anninbarrett@gmail.com

Carol Bier

The Textile Museum, bier.carol@gmail.com

Anna Jolly

Abegg-Stiftung, jolly@abegg-stiftung.ch

Louise W. Mackie

Imackie184@outlook.com

Barbara Setsu Pickett

University of Oregon, bpickett@uoregon.edu

Follow this and additional works at: https://digitalcommons.unl.edu/tsaconf

Part of the Art and Materials Conservation Commons, Art Practice Commons, Fashion Design Commons, Fiber, Textile, and Weaving Arts Commons, Fine Arts Commons, and the Museum Studies Commons

Barrett, Annin; Bier, Carol; Jolly, Anna; Mackie, Louise W.; and Pickett, Barbara Setsu, "India in Situ: Textile History and Practice, a Team Approach" (2020). Textile Society of America Symposium Proceedings. 1191.

https://digitalcommons.unl.edu/tsaconf/1191

This Article is brought to you for free and open access by the Textile Society of America at DigitalCommons@University of Nebraska - Lincoln. It has been accepted for inclusion in Textile Society of America Symposium Proceedings by an authorized administrator of DigitalCommons@University of Nebraska - Lincoln. 


\section{India in Situ: Textile History and Practice, a Team Approach}

Annin Barrett, Carol Bier, Anna Jolly, Louise W. Mackie, Barbara Setsu Pickett anninbarrett@gmail.com, bier.carol@gmail.com, jolly@abegg-stiftung.ch, Imackie184@outlook.com, bpickett@uoregon.edu

\section{Introduction \\ Barbara Setsu Pickett}

Like in planetary formation, our research team coalesced. We were five individuals swirling around, busy in our own orbits. The Textile Society of America Symposium in Vancouver, BC, in 2018 brought us together with common interests surrounding my paper "Rahul Jain's Reimagined Indian Velvet Drawloom." In attendance were Annin Barrett, Carol Bier and Louise Mackie. At the end of my talk, Louise proposed a return trip to India: our separate, nebulous plans took form.

We knew each other to varying degrees. In my case, Annin is a longtime friend and valued colleague: we both are textile educators and artists based in Oregon. Carol, I knew from the book she authored, The Persian Velvets at Rosenborg (1995) and the volume she edited, Woven from the Soul, Spun from the Heart: Textile Arts of Safavid and Qajar Iran 16th-19th Centuries (1987), and from working on her TSA Toronto session, Textiles Plus Math Equal Infinity in 2006. Louise, I hadn't yet met, but knew from her definitive tome, Symbols of Power: Luxury Textiles from Islamic Lands, 7th-21st Century (2015) and from her work at the Cleveland Museum of Art and the Textile Museum in Washington, DC. Louise recommended that Anna Jolly, curator of sixteenth to eighteenth century textiles at the Abegg-Stiftung Museum, join the group since they already had preliminary plans for a research trip to India. Mutual trust and reliance on each other's experience and expertise increased as we communicated by email.

Rahul Jain's mission is to bring back five complex weave structures historically woven on Indian drawlooms: taqueté/samite, lampas, brocaded double cloth, discontinuous weft-substituting twill, and velvet. When Rahul invited me in 2016 to come and see the velvet drawloom, I eagerly accepted. Handweaving of silk velvet has been the focus of my research and artwork since 1981. I have studied velvet techniques and processes in ateliers in Italy, France, England, Japan, China, Turkey and Uzbekistan. Rahul cautioned me that his loom was the product of experimentation and conjecture since the historical record lacks continuity and no descriptions of the looms exist. Rahul credits the success of this project to his team headed by master weaver Shamim Ansari and Abhishek Jain, a postgraduate student in Textiles from the National Institute of Design in Ahmedabad. When Rahul wrote that he would not only welcome us but join us in Varanasi and Cholapur, we were elated. He recommended at least four days together. I contacted Indebo, the travel agency I had used in 2016, which specializes in tours featuring artisans at their traditional crafts. They handled all the logistics including lodgings and internal transportation. Our itinerary gelled into 21 days packed with textile adventures.

\section{Research Goals}

Barbara Setsu Pickett: The main goal of my return trip was to fill in the gaps of my understanding of the velvet drawloom and its operations. I thought that I had understood the basic workings but discovered after my return that several vital points needed further clarification. Questions arose: How can the master weaver control the 21 shafts with only seven treadles and weave the pile, satin

Published in Hidden Stories/Human Lives: Proceedings of the Textile Society of America 17th Biennial Symposium, October 15-17, 2020. https://digitalcommons.unl.edu/tsaconf/ Copyright @ 2020 Annin Barrett, Carol Bier, Anna Jolly, Louise W. Mackie, Barbara Setsu Pickett doi: 10.32873/unl.dc.tsasp.0131 
ground weave, and facing wefts? Or how does the woven velvet keep tension without being crushed while on the loom? What are the tricks to find and repair broken threads?

Secondly, I wanted to know how the naqshband, the master pattern harness maker, went from initial design sketch to finished pattern mounting. The naqsha is a complex system of knotted cords that is the soul of the drawloom. At first it seems mechanical, a series of pick-up lifts, then you notice subtleties. Like in music, the design sketch is merely the score, and the naqshband is the conductor who breathes life into the notes. The artistry and finesse lie in making a myriad of finely tuned choices. I wanted to learn the factors at play and the criteria at work. Underlying all my questions was the nagging query, do I know enough to do it myself? Shortcomings in my comprehension flagged the need for further research. Perhaps it is impossible to fully understand all on the first encounter and return investigations are to be expected.

Lastly, I wanted to show my deep appreciation and gratitude to Rahul and his team by giving Rahul a ciselé velvet that I wove on a manual Jacquard loom at the Fondazione Lisio in Florence, Italy and by giving the team a genuine Italian velvet wire and recently made velvet knife. This sharing of information and knowledge is a joy for me and builds lasting relationships and goodwill.

Louise W. Mackie: Ever since the 1990s, I had wanted to see the drawlooms recreated in India by Rahul Jain. ${ }^{1}$ In his booklet Minnāka $r$, he stated that after setting up a drawloom workshop in New Delhi, the silk weavers succeeded in weaving the compound weaves, but not how to refine the texture, pattern and weight. "We could not anticipate that it would take some three years of continuous development to match the superb physical quality of the Mughal Indian or Safavid Iranian work."2 Now, 25 years later, they are still refining their velvet technique (fig. 52).
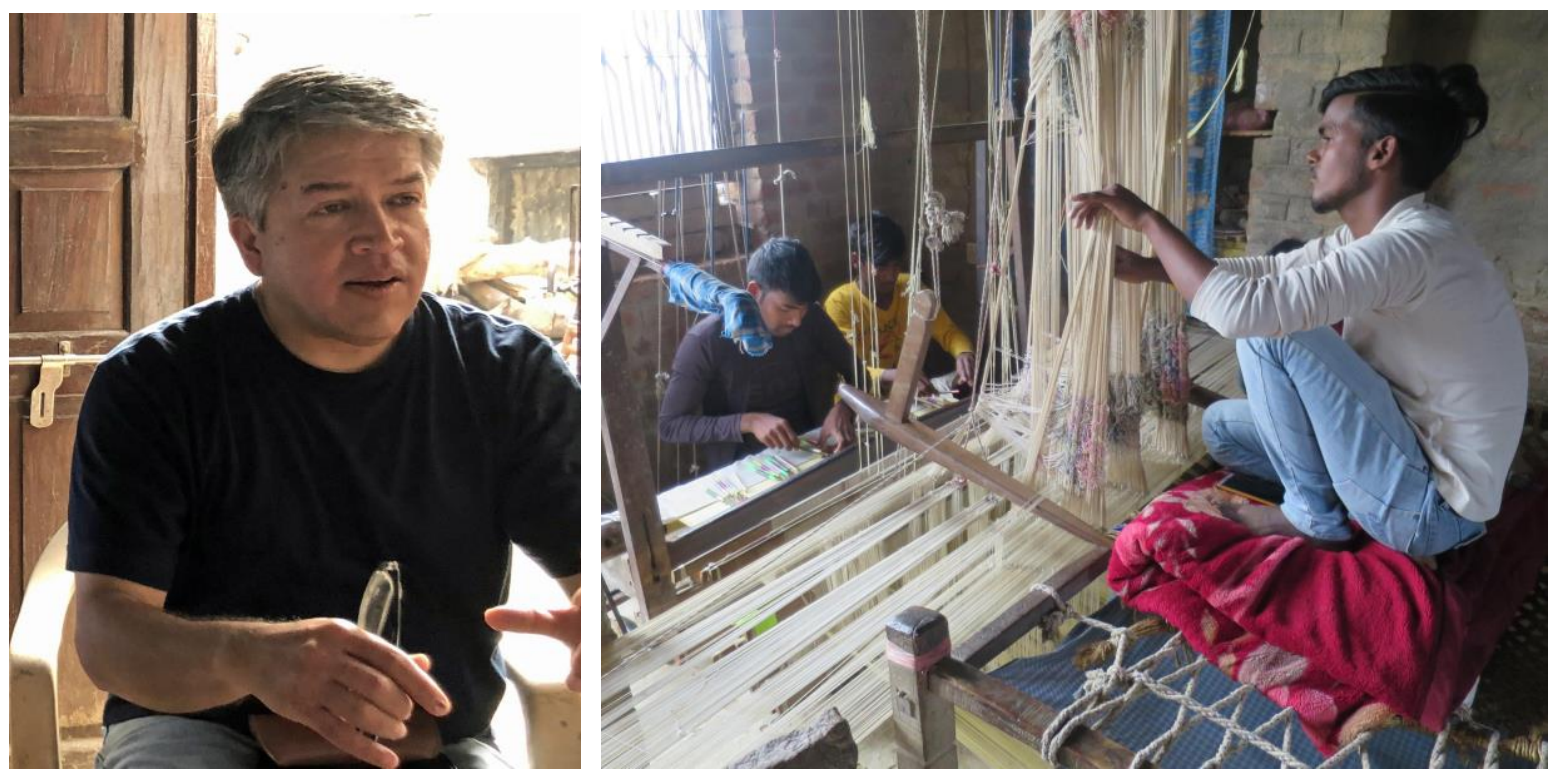

Fig. 1 Rahul Jain, Textile Designer, Manufacturer, Scholar, Historian and Author. Fig. 2 ASHA drawloom, Cholapur near Varanasi. Photos: Anna Jolly, 2020

\footnotetext{
${ }^{1}$ Rahul Jain, Mīnākār. Spun Gold and Woven Enamel (New Delhi: Textile Art, 1997). For a summary, see Louise W. Mackie, Symbols of Power. Luxury Textiles from Islamic Lands, $7^{\text {th }}-21^{\text {st }}$ Century (The Cleveland Museum of Art, New Haven and London: Yale University Press, 2015), 456-58, figs.11.9-11.11, 11.20.

${ }^{2}$ Jain, Mìnākār, 5 (not paginated).
} 
In 1988, Rahul Jain was an economist working at the World Bank, in Washington, D.C. He took a weaving workshop where he read a Textile Museum Journal article on royal Mughal sashes. ${ }^{3}$ They transfixed him and changed his life. Inspired by seeing a royal sash through a microscope in the Textile Museum, thanks to curator Carol Bier, Rahul enrolled at the Philadelphia College of Textiles and Science. In 1993, he set up ASHA, a drawloom workshop in New Delhi, now relocated to Cholapur near Varanasi. One of Rahul's earliest designs displays elegant Mughal-style irises on a brilliant golden ground which characterized Mughal silks originally and includes an inscribed cartouche in the field: Irises circa 1700, woven for ASHA by Anwar Ahmad, Delhi, $1993 .{ }^{4}$
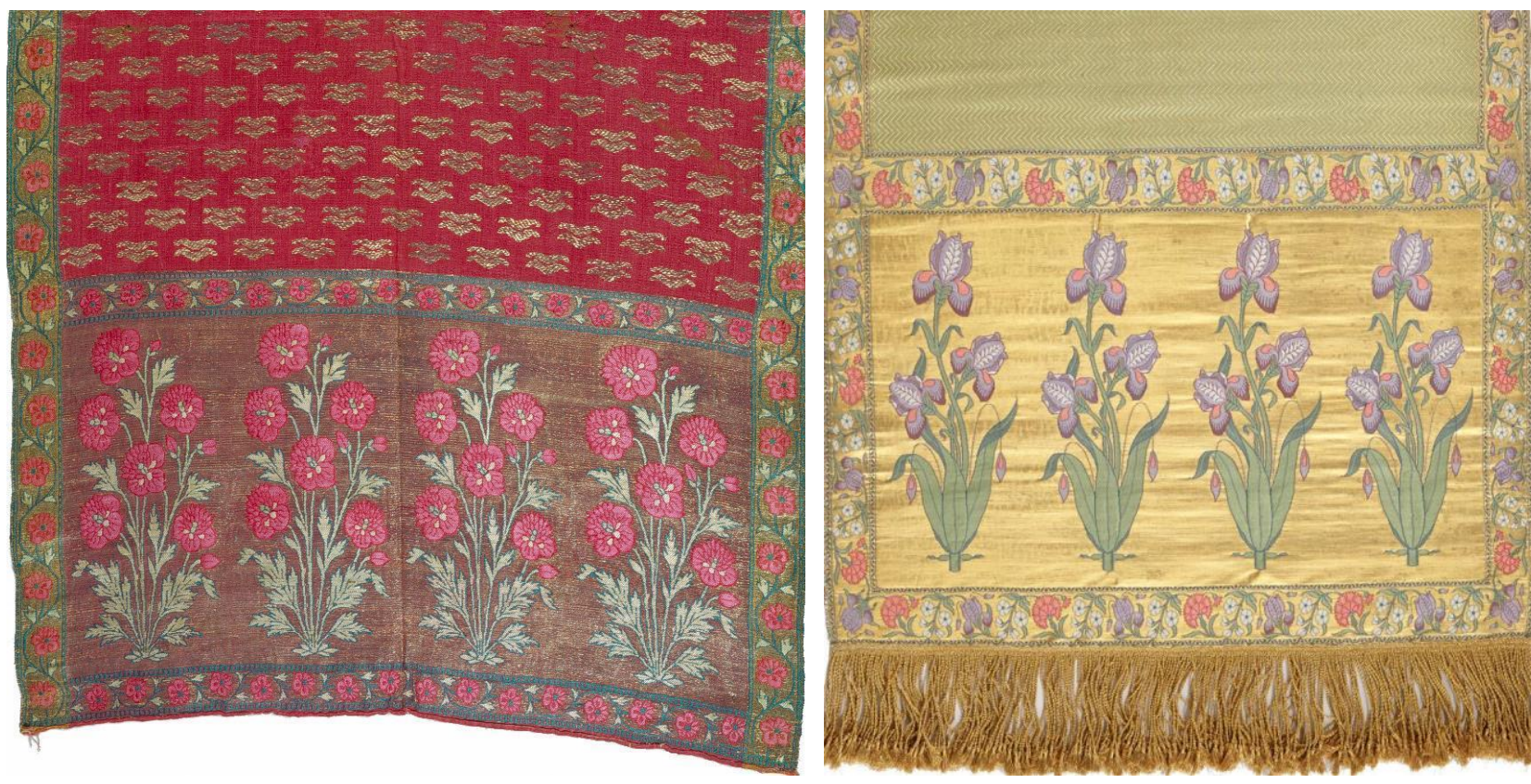

Fig. 3 Sash (patka), India, mid-17th century, detail, The Textile Museum, Washington, D.C., 6.29, acquired by George Hewitt Myers in 1928. Fig. 4. Sash (patka), India, ASHA 1993, detail, The Textile Museum, Washington, D.C., 1994.10.1, Museum purchase: The Ruth Lincoln Fisher Memorial Fund. Photos: Courtesy of The Textile Museum

Rahul Jain has many talents. He is an award-winning designer, manufacturer, textile technician, scholar, and author and a delightful human being. The National Museum in New Delhi celebrated 25 years of ASHA's stunning production with 43 of his radiant silks in the exhibition entitled PraKashi: Silk, Gold and Silver from the City of Light (2019).

Rahul Jain inspired all of us; he was the catalyst of our collaborative research trip in India. We highly recommend his seminal and beautifully illustrated book, Rapture: The Art of Indian Textiles (fig. 6), the first to examine Indian textiles of numerous cultural contexts, functions, and techniques from the fourteenth to the twenty-first century. ${ }^{5}$

\footnotetext{
${ }^{3}$ Milton Sonday and Nobuko Kajitani, "A Type of Mughal Sash,” Textile Museum Journal 3, no. 1 (1970): 45-54; Milton Sonday and Nobuko Kajitani, "A Second Type of Mughal Sash,” Textile Museum Journal 3, no. 2 (1971): 6-12. ${ }^{4}$ For the entire length of the sash with cartouche, see Louise W. Mackie, "Increase the Prestige: Islamic Textiles," Arts of Asia 26, no. 1 (1996): fig. 76.

${ }^{5}$ Rahul Jain, Rapture: The Art of Indian Textiles (New Delhi: Niyogi Books, 2011).
} 

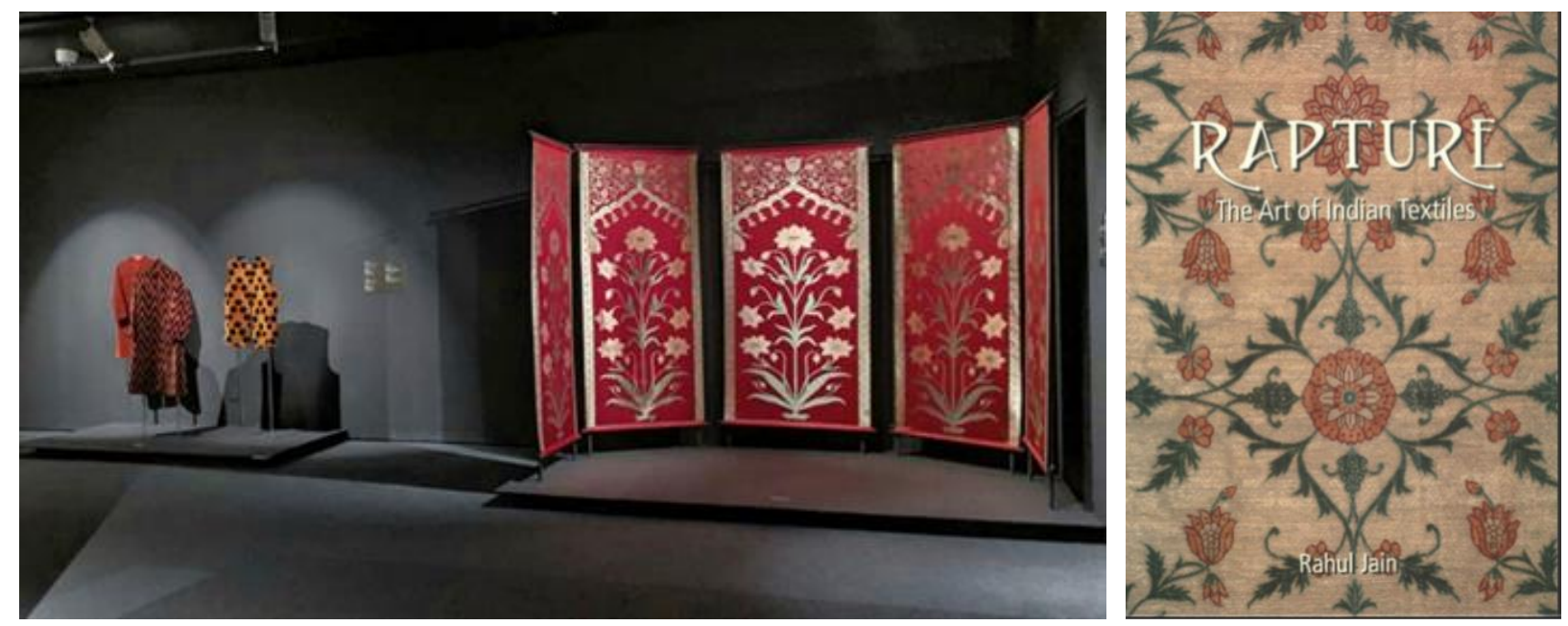

fig. 5 Pra-Kashi: Silk, Gold and Silver from the City of Light, ASHA 25th Anniversary Exhibition, National Museum, New Delhi, 2019. Photo: Rahul Jain. Fig. 6 Book cover, Rahul Jain, Rapture. The Art of Indian Textiles, 2011.

In New Delhi, Carol Bier, Barbara Setsu Pickett, and I delighted in feasting with the celebrated gourmand, Jasleen Dhamija, cookbook author and pioneering craft revivalist, textile specialist, and significant author whose books have inspired each of us (fig. 7). ${ }^{6}$ Jasleen's textile passion extended to her excitement in meeting velvet weaver Barbara Pickett.

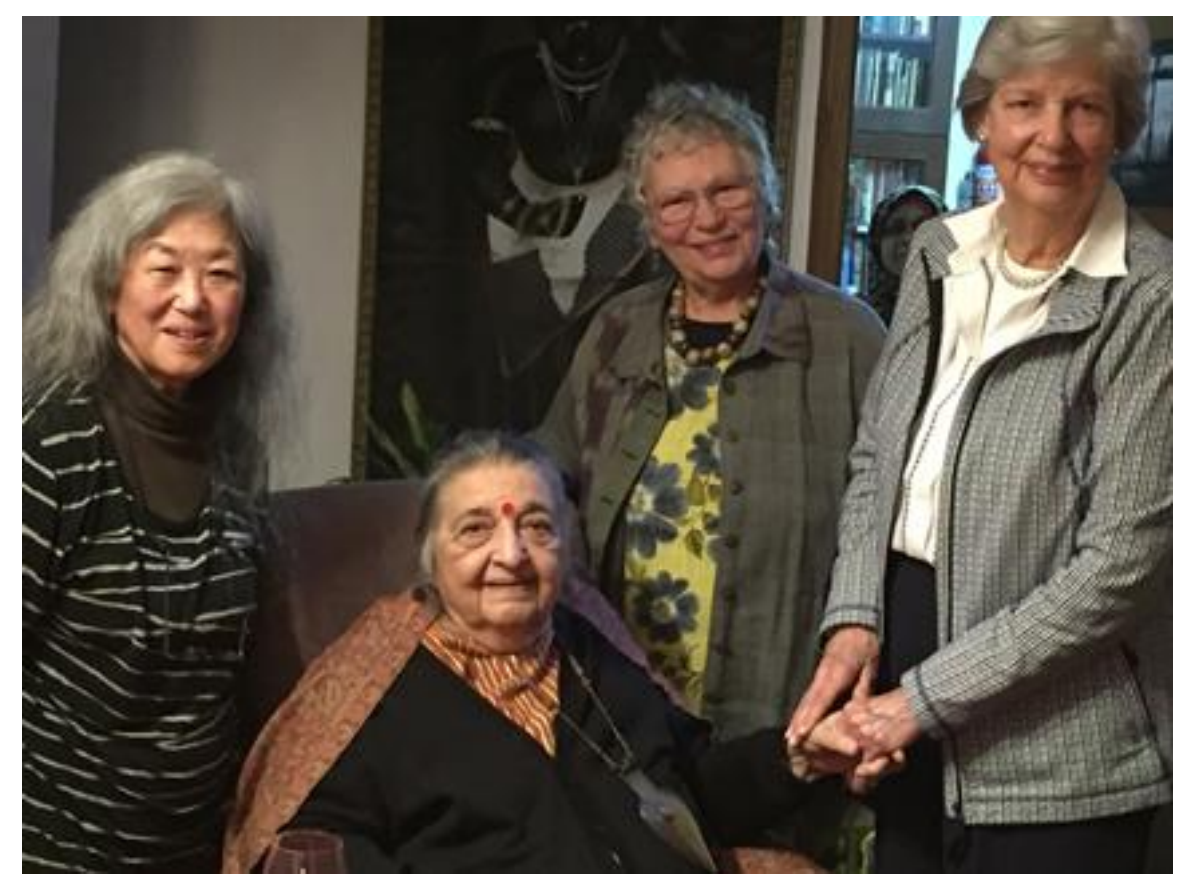

Fig. 7 Textile revivalist and author, Jasleen Dhamija (seated) with Barbara Setsu Pickett, Carol Bier, and Louise Mackie, in New Delhi, February 2020. Photo: Courtesy of Choteylal

\footnotetext{
${ }^{6}$ Jasleen Dhamija (contributing author), Baluchari: Bengal and Beyond (Kolkata: Weavers Studio Resource Centre, 2016); Jasleen Dhamija, Living Traditions of Iran's Crafts (New Delhi: Vikas, c1979); Jasleen Dhamija, ed. Crafts of Gujarat ([Ahmedabad] New York: Mapin, 1985); Jasleen Dhamija and Jyotindra Jain, eds. Handwoven Fabrics of India (Ahmedabad: Mapin, 1989); Jasleen Dhamija, ed. The Woven Silks of India (Mumbai: Marg Publications, 1995). See also, Jasleen Dhamija, Gourmet's Journey: Discovering the Exotic \& Erotic in Food (New Delhi: Women Unlimited, 2018).
} 

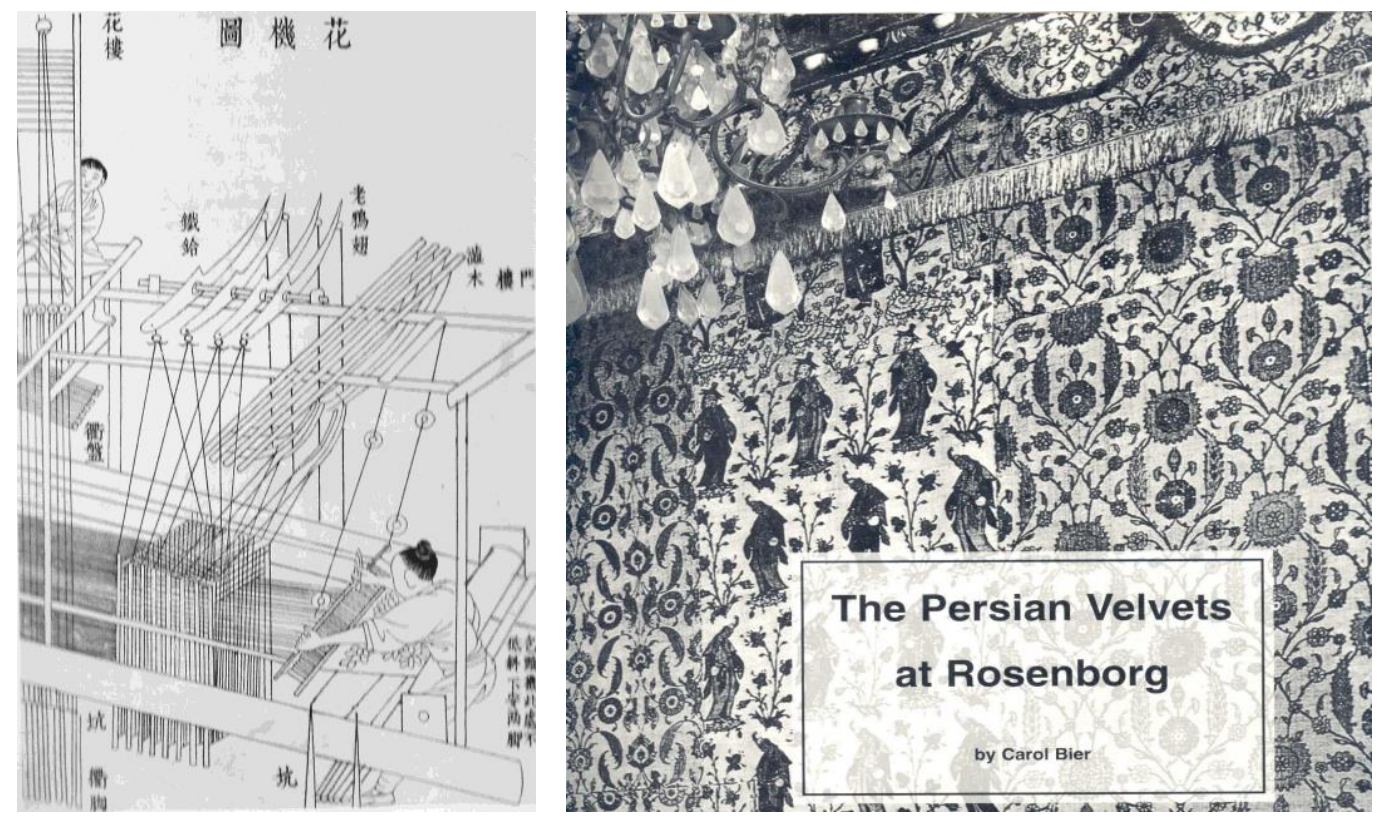

Fig. 8 Chinese drawloom, 17th century (reproduced in Bier, The Persian Velvets at Rosenborg (Copenhagen, 1995), fig. 5.

Fig. 9 Book cover, Carol Bier, The Persian Velvets at Rosenborg, 1995, depicts Persian velvets as wall covering.

Carol Bier: The questions I brought concerned historical, technological, and cultural topics, and derived in part from my research on the corpus of seventeenth-century Persian velvets at Rosenborg Palace in Copenhagen, and compound weaves more generally, focused on drawloom technology and its history. First, did the technology move from east to west, or west to east? And how might the technology have spread? And might the Astana finds, excavated by Aurel Stein in western China in the early twentieth century and housed in the National Museum in New Delhi, shed any light on our understanding? Related to these concerns, I sought a deeper understanding of the process of drawloom weaving, which I could explore in India: Specifically, what exactly is the means of tying up the naqsha and how does it work to control the pattern? And I hoped I might locate historical connections to Central Asian weaving and Bukhara, where the Naqshbandi order in Sufism originated -- the naqshband being the pattern maker who ties up the naqsh, so the one responsible for making the harness mechanism that controls repetition of the pattern.

Addressing separate concerns related to design-structure-technology-function, I wondered what relationships I could discern between architecture and textiles. In particular, I wanted to learn more about ornament in Mughal architecture in relation to patterns in textiles (as observed on trips to India in 2015 and 2016). And what historical relationships existed between Safavid Iran and Mughal India that may have contributed to any similarities observed.

Given how arcane these questions are, you can perhaps imagine how thrilled I was to partake of a traveling seminar with four sympathetic, curious textile colleagues, not all of whom I knew, but now all dear friends.

Anna Jolly: Louise and I had talked for many years about travelling together to India to see Rahul Jain's drawlooms and to study historical textiles in some of India's museum collections. When she suggested that we join three other experienced colleagues, I was thrilled and immediately consented to come along. I am currently researching Indian and Iranian textiles of the sixteenth to the eighteenth century in the Abegg-Stiftung for a future catalogue raisonné of this part of its 
collection. The Abegg-Stiftung is a private foundation and textile research center with a museum and a textile conservation workshop in Riggisberg, Switzerland (figs. 10-11).
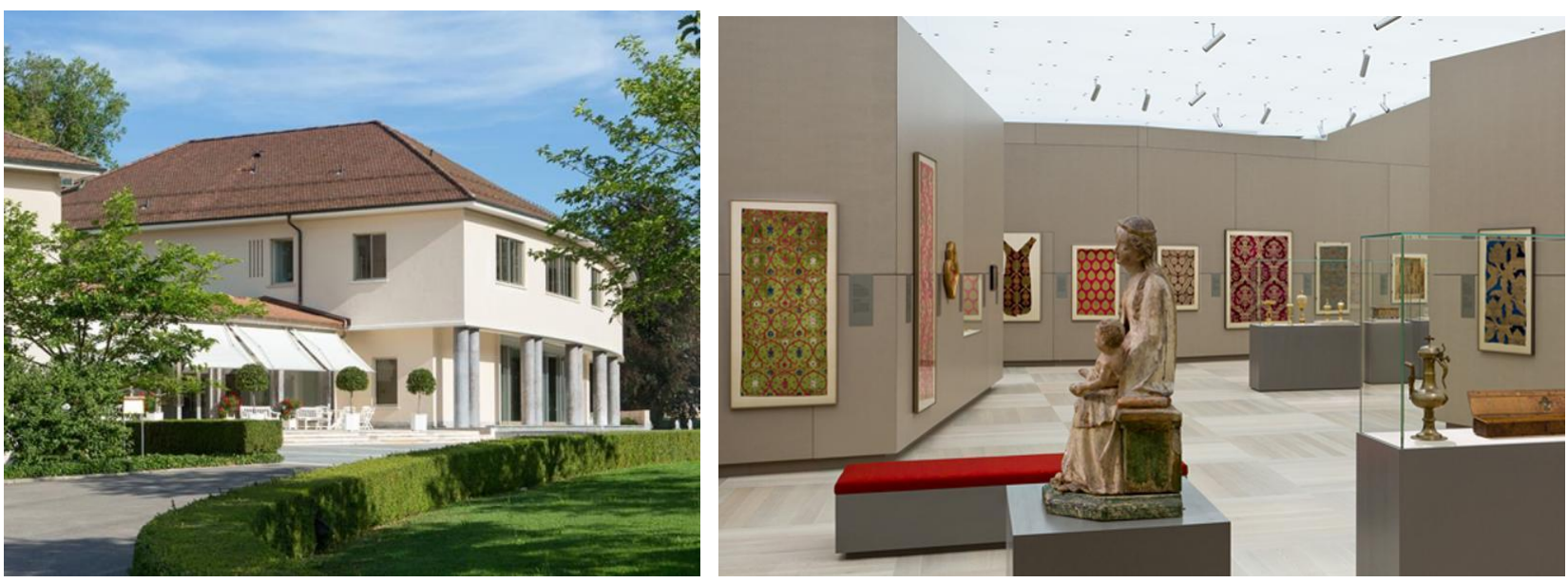

Fig. 10 Abegg-Stiftung, Riggisberg, Museum building with main entrance. Fig. 11 View of the galleries. Photos: Abegg-Stiftung, Christoph von Viràg, 2016

As a museum curator, I believe that the best way to gain an understanding of textiles is to study the originals at first hand. This allows us to become familiar with their physical characteristics as well as their compositions, colors and weaving techniques. Traveling to see the original textiles as well as their former architectural settings is in my opinion indispensable for a true understanding of the material. Our visits to historical monuments in the company of such well-renowned specialists of Islamic art as Carol Bier and Louise Mackie added another dimension to making this trip a truly once-in-a-lifetime experience for me.

Annin Barrett: My desire to go on this journey was threefold: first, Barbara Setsu Pickett's previous research trip to India fascinated me, especially because this is a country with a continuous, living tradition of handcrafted textiles, from ancient times through today. Barbara's work with handwoven silk velvet inspires me and her study of Rahul Jain's project piqued my curiosity. This opportunity to visit weaving villages and meet textile artists was irresistible.

Second, as a sustainable design educator, I hoped to learn how the long heritage of textile creation in India could inform sustainable practices now. In particular, I wanted to see how a renewed interest in natural indigo dye in India (where it originated), water conservation, and the concept of local production, might help reinvent the future of textile and fashion design. From a designer friend at Nike, Namrata Amin, I had introductions to professors at two Indian design colleges that opened doors of potential research for sustainable design.

And third, the prospect of traveling with four eminent textile scholars, with access to seldom-seen historic textile collections was a dream come true. Carol Bier's knowledge of Islamic architectural patterns reawakened a latent passion of mine. Louise Mackie helped me see connections between textiles and formal garden designs that I hadn't realized were there. Barbara Setsu Pickett and Anna Jolly's deeply insightful explanations of Rahul Jain's looms all contributed to an extraordinary research trip. 


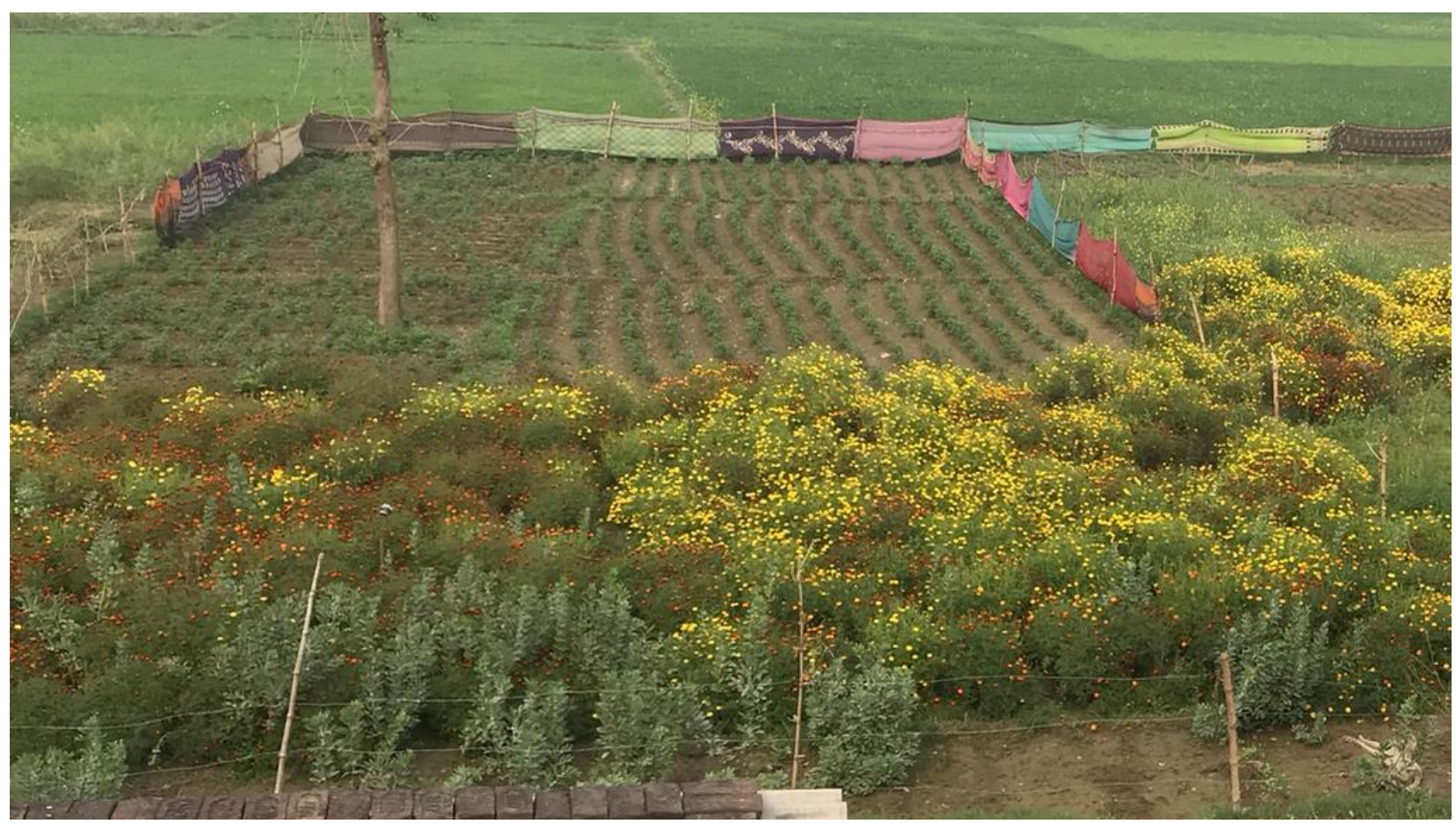

Fig. 12 Fields in Cholapur, Varanasi, surrounded by fences made with old saris. Photo: Carol Bier, 2020

\section{Textiles and Architecture}

Carol Bier

One of the questions left inadequately answered from my travel in India in 2016 concerned the relationships that could be discerned between textiles and architecture. I anticipated answers that would entail proportional systems, symmetry as an aesthetic principle for both three-dimensional structures and two-dimensional patterns, and I expected to find both representation of architecture in textiles and of textiles in architecture. I admit I quickly learned how naïve this question was, but having raised it, I was made more aware and my eyes and mind were open to new observations and concerns. One initial observation, contrary to expectation, was seeing the cultivation of orange and yellow calendula with fences made of old saris strung up to protect the fields.

The relationships I could discern between textiles and architecture yielded four discrete categories:

1) textiles as architecture, such as tents and fences (fig. 12);

2) textiles in architecture, such as furniture and furnishings (figs. 15-16);

3) the representation of architecture in textiles (fig. 17);

4) the representation of textiles in architecture (figs. 13, 18).

These contrasting categories are not unique to India; but they are especially apt there because of the rich traditions of both textiles and architecture, and the diverse range of technologies still at play. Needless to say, there is considerable overlap in these categories and much ambiguity; I found this to be especially true regarding the representation of textile structures in architecture and architectural ornament (figs. 13 and 18). 
The most familiar example of textiles as architecture is, of course, the tent; in India, there is indeed a long history of royal tents, portable palaces as well as military tents, likely derivative of an earlier history in Central Asia. ${ }^{7}$ Royal tents and pavilions are frequently illustrated in manuscripts, and often include exterior space-defining walls made with textiles. ${ }^{8}$ Then there are awnings and canopies erected above open space, as well as drapes and curtains that separate interior spaces from exterior. Extant Mughal royal tents of red velvet (red was the royal color) are outfitted with reed screens (chikh), as for example one from the late seventeenth or early eighteenth century, held in the Mehrangarh Trust Museum, Jodhpur, Rajasthan. ${ }^{9}$ Royal tents and pavilions, expressive of power and sovereignty, reflect the use of opulent textiles as architecture, but they also always depended upon the use of highly prestigious textiles in architecture, which included not only awnings, canopies, drapes and curtains, but also furnishings, such as carpets, bedding, covers, bolsters, and cushions - to say nothing of royal garments and sashes.
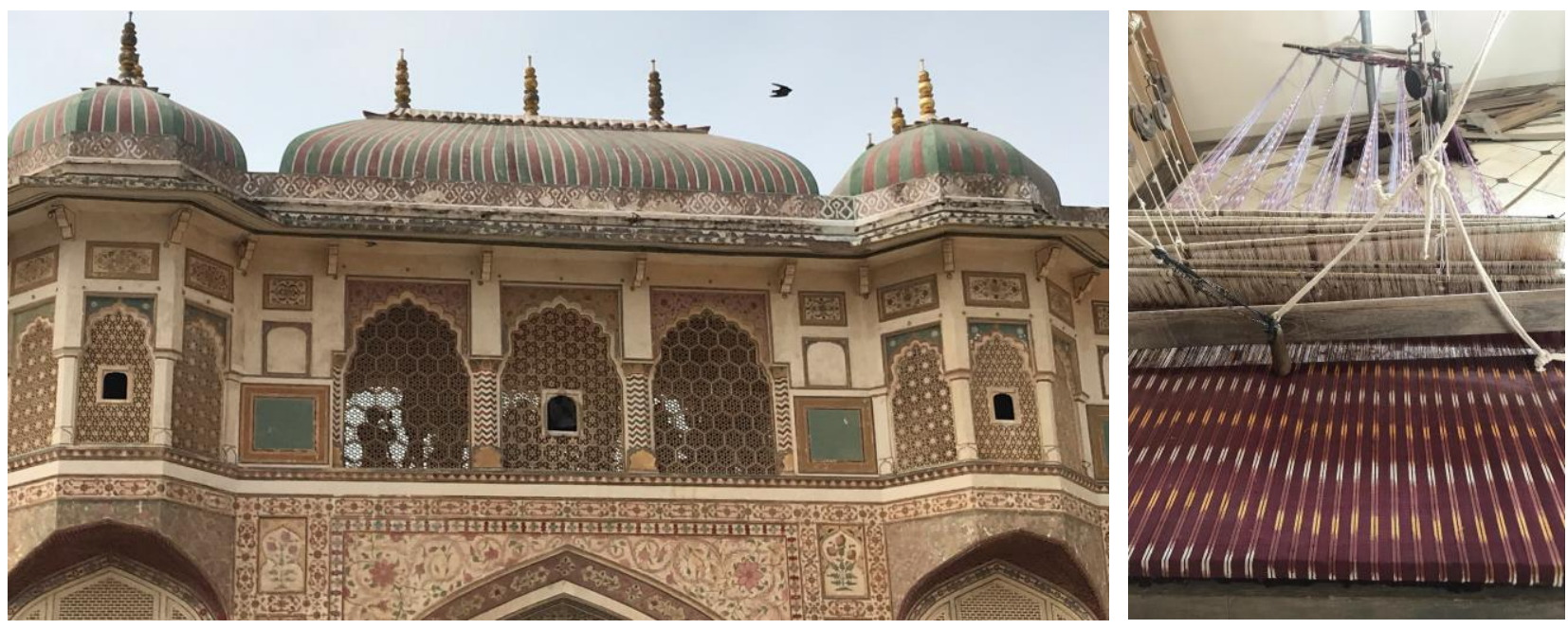

Fig. 13 Divan-e Khas, Amber Palace, Rajasthan, 17th century. Fig. 14 Weaving mashru, Patan, Gujarat. Photos: Carol Bier, 2020

Some architectural features may actually reflect tent structures and forms, such as the rooflines and finials of the Hall of Private Audience (Diwan-i Khas) of Rajput rulers at the Amber Fort (fig. 13). Their striped exterior and interior surfaces are reminiscent of mashru, the distinctive striped textiles that are warp-patterned with resist-dyed warps (fig. 14); the stripes, and contrasting colors, are preserved in aesthetic choices of wedding tents today.

Two unusual aspects of textiles in architecture in India are the ubiquitous traditional rope beds (char pai) so suitable to such a hot climate, with their signature interlacing (fig. 15), and the characteristic reed screens (chikh) used to shade light, where cut grasses or reeds serve as weft (fig. 16). Several experiments we saw at the National Institute of Design in Ahmedabad led me to recognize several adaptive textile structures - where the weft is stiff, tessellations could be created

\footnotetext{
${ }^{7}$ Peter A. Andrews, Felt Tents and Pavilions: The Nomadic Tradition and Its Interaction with Princely Tentage (London: Melisende, 1999).

${ }^{8}$ For example, see illustration, "The Amir seizes the Queen of Zarsuhusht and makes her Muslim," in the Hamza Nama, c.1557-77, in MAK, Vienna (purchased, 1873), https://sammlung.mak.at/en/collection_online?id=collect200235 (accessed 3 January 2021).

${ }^{9}$ Zirwat Chowdhury, “An Imperial Mughal Tent and Mobile Sovereignty in Eighteenth-Century Jodhpur,” Art History (4 September 2015), pp. 668-681. DOI: 10.1111/1467-8365.12174 (accessed 3 January 2021).
} 
by manipulating the warp, deflecting warp elements, a technique more familiar in embroidery. This, in turn, raised my awareness of knotted netting, used as a space divider, defining and enclosing space within an architectural setting.
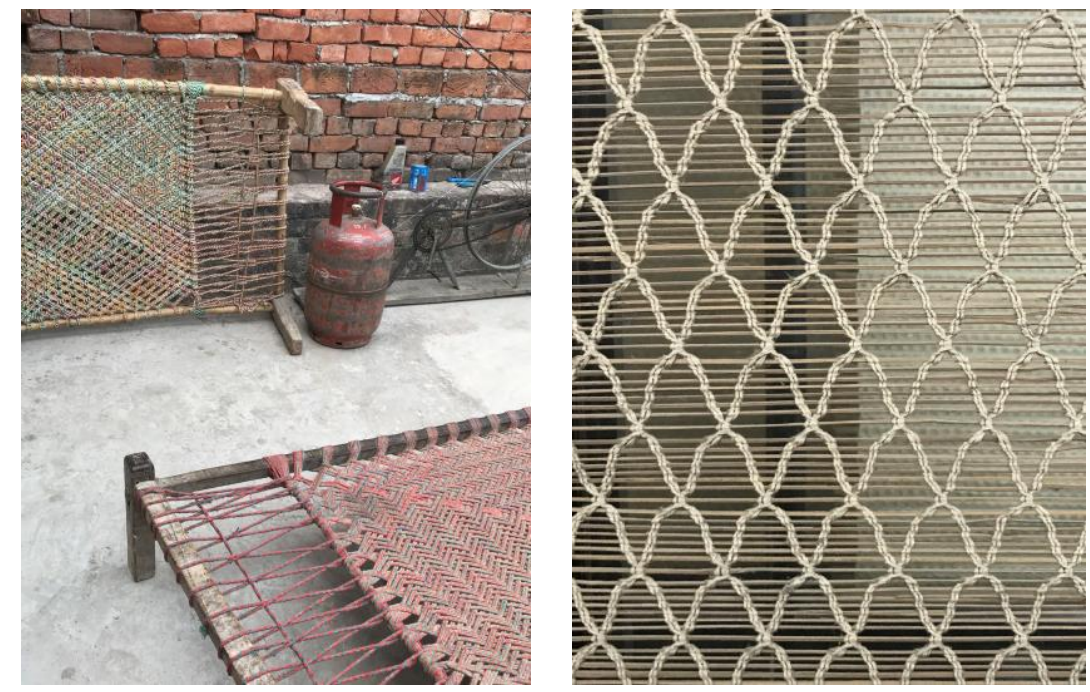

Fig. 15 Traditional bed (char pai) with interlacing, Cholapur. Fig. 16 Reed screen (chikh), National Institute of Design, Ahmedabad. Photos: Carol Bier, 2020

As for the representation of architecture in textiles, two characteristic examples include the textile panels referred to as qanat, depicting arches and columns, which served as free-standing exterior walls and to line tent interiors (figs. 26 and 31). ${ }^{10}$ A second example is the representation of Persian gardens with their characteristic four-fold layout, chahar bagh in carpets (figs. 17 and 40), a form adopted by the Mughals for the design of their own royal gardens (figs. 41 and 42). ${ }^{11}$

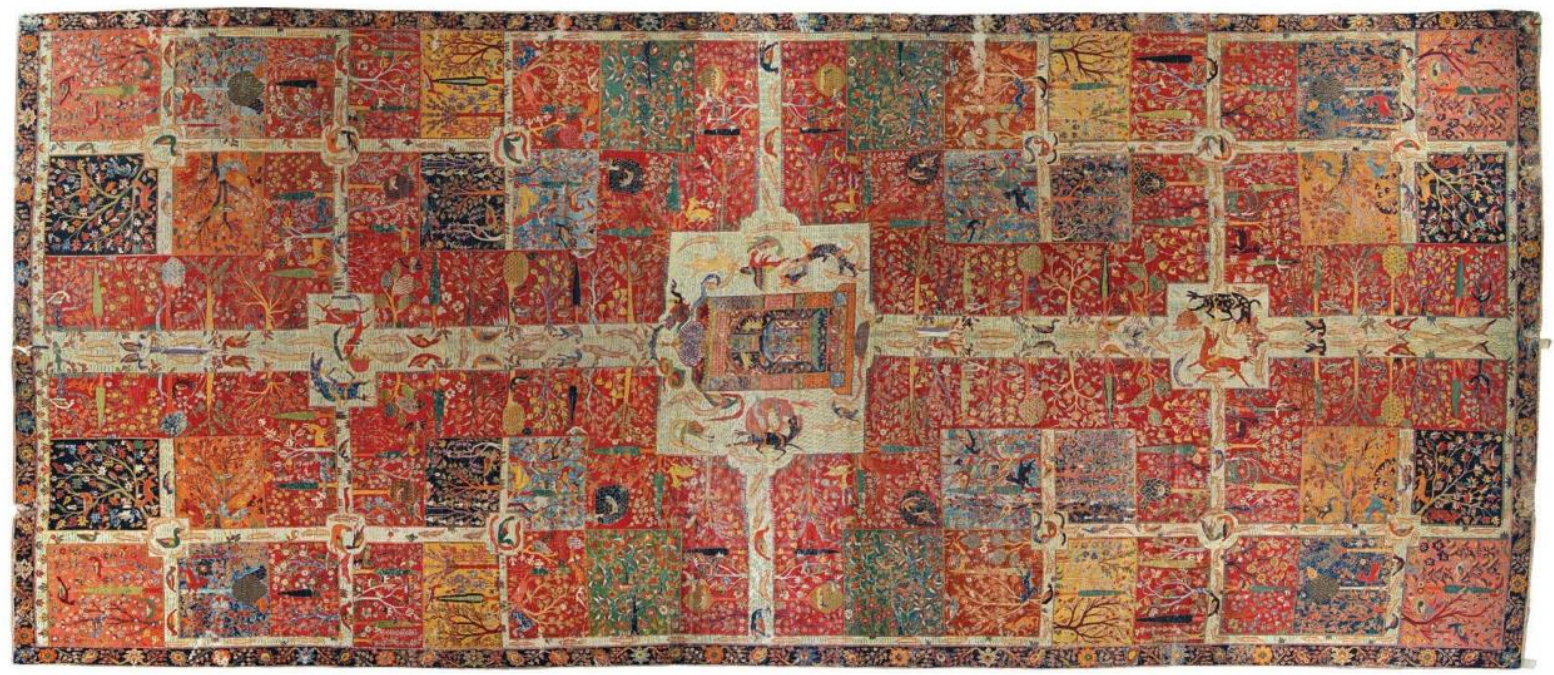

Fig. 17 Garden carpet, c. 1600, Iran. Albert Hall Museum, Jaipur (no. 681/225). Photo: courtesy Government of Rajasthan Department of Archaeology and Museums/Mapin Publishing

\footnotetext{
${ }^{10}$ Peter A. Andrews and Mugul Andrews, Tentage at the Calico Museum and Its Patterns (Ahmedabad: Sarabhai Foundation, 2015).

${ }^{11}$ Bruce Healy, "The Jaipur Garden Carpet,” Hali (March 30, 2020) https://hali.com/articles/the-jaipur-garden-carpet/ (accessed 3 January 2021).
} 
For the representation of textiles in architecture, I was struck by the diverse array of panels of carved stone in the eleventh-century Step Well at Rani Ki Vav in Gujarat with designs based on an oblique square grid (fig. 18), and how parallel they are visually to the patterns on textiles woven nearby at Patan (fig. 19). The patterning in the textiles is created by resist of both the warp and the weft (double ikat), which are prepared and dyed prior to weaving. The resist pattern of the weft is carefully matched to that of the warp, making a square grid in plain weave. I was also taken with simple striped zig-zag patterning we encountered in Agra at the Taj Mahal (1632-48), executed in cut stone inlay, both in the characteristic local red sandstone, and in the Taj Mahal's worldrenowned white marble; in both instances, I see reference to the characteristic reverse repeats of split-ply braiding, or that of card-weaving (charpana) a traditional textile technology in India and elsewhere in South and Central Asia. ${ }^{12}$ But we also found the same design executed using block printing, and in velvet weaving. A detail of stone-carving in white marble seen throughout the Taj Mahal is the outlining of arched iwans with 'rope moldings,' which visually relate to plied marble, or marble cords. ${ }^{13}$

Akbar's tomb complex at Sikandra (1605-13) offered a medley of patterns in inlaid sandstone, many of which bear resemblance to textile patterns. In particular, two vertical panels show an arrangement of square and rectangular elements of cut stone inlay that range in proportion $3: 2: 1$, which I again liken to card-weaving, but it could as well be tapestry or kilim, and we found a parallel also in Gujarati embroidery with mirror work. A more complex level of patterning is seen in a vaulted ceiling of Akbar's tomb in Sikandra, where a complex symmetrical design of floral ornament with cloud bands and geometry, finds parallels in Indo-Persian carpets. ${ }^{14}$

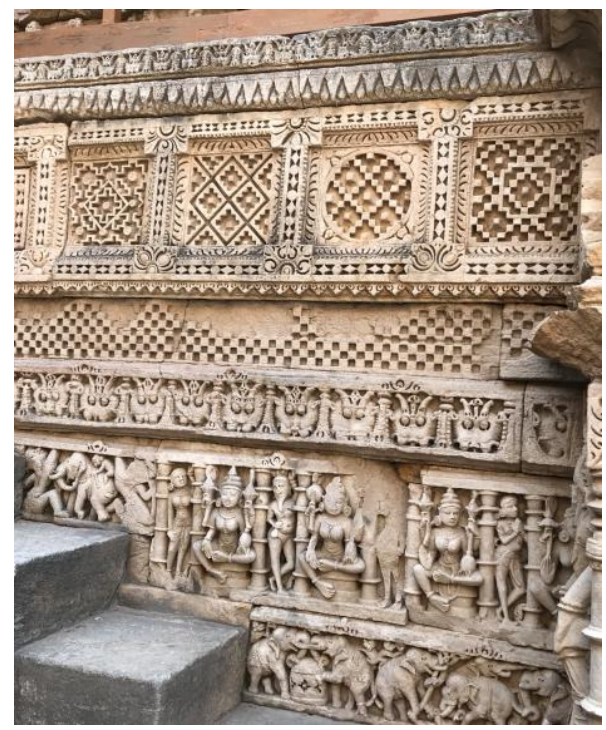

Fig. 18 Stepwell, 11th century, Rani Ki Vav, Gujarat. Fig. 19 Weaving patola, in Patan, Gujarat. Photos: Carol Bier, 2020

\footnotetext{
${ }^{12}$ Peter Collingwood, The Techniques of Split-Ply Braiding (Petaluma, CA: Unicorn Books, 1998).

${ }^{13}$ Lisa Golombek and Ebba Koch, "The Mughals, Uzbeks, and the Timurid Legacy," in A Companion to Islamic Art and Architecture. Ed., F. B. Flood and G. Necipoğlu (Hoboken NJ: John Wiley \& Sons, 2017), 837.

${ }^{14}$ Daniel S. Walker, Flowers Underfoot: Indian Carpets of the Mughal Era (New York: The Metropolitan Museum of Art, 1997).
} 
Finally, I would like to address - all too briefly - my revelation concerning the naqsha, the enigmatic device (figs. 20, 21) that is historically used to implement a repeat pattern in drawloomweaving. What looks like a messy bundle of strings is really a compressed bundle of logic. Like magic, designed by a naqshband, it programs the warps during weaving, which through raising and lowering, it enables the weaving of a repeated design that is integral with the ground weave, which forms a pattern. Accompanying my epiphany regarding this messy form of logic is its inherent portability, which could conceivably have contributed to the yet enigmatic transmission of this advanced textile technology across Asia.
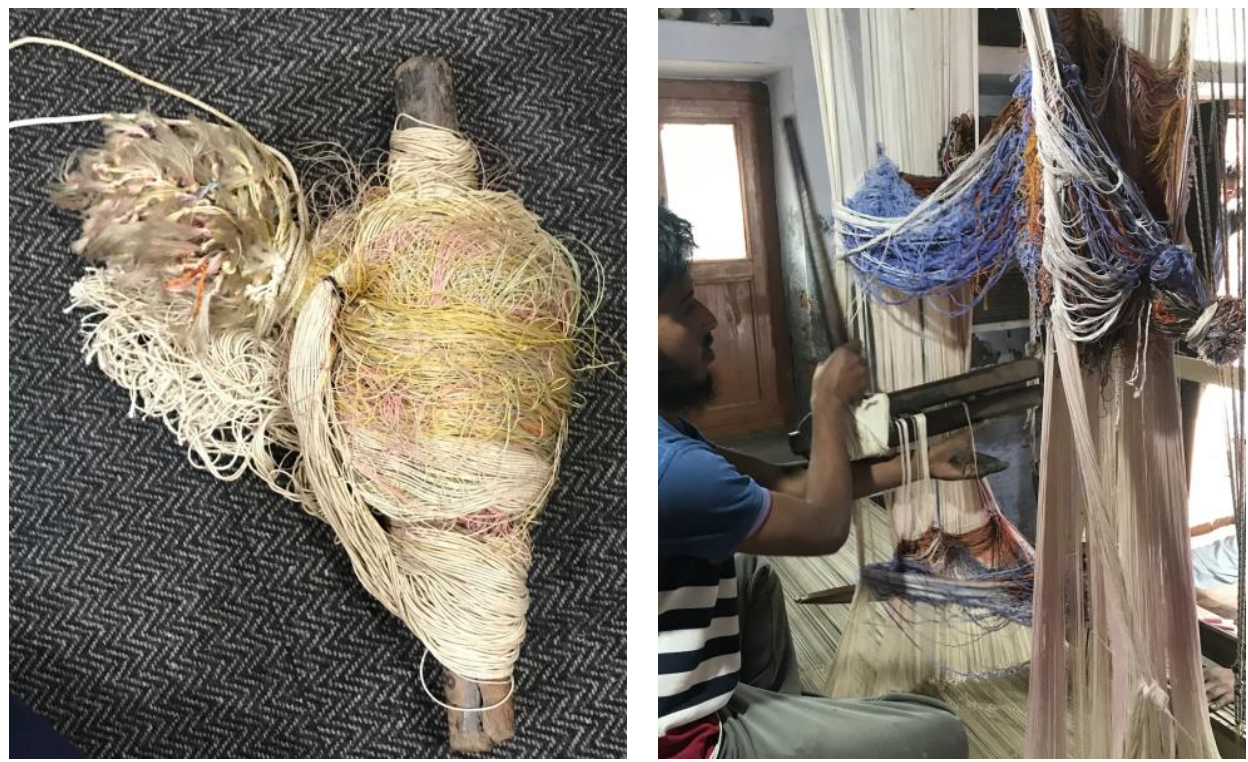

Fig. 20 Naqsha, Varanasi. Fig. 21 Drawloom with naqsha, Cholapur, Varanasi. Photos: Carol Bier, 2020

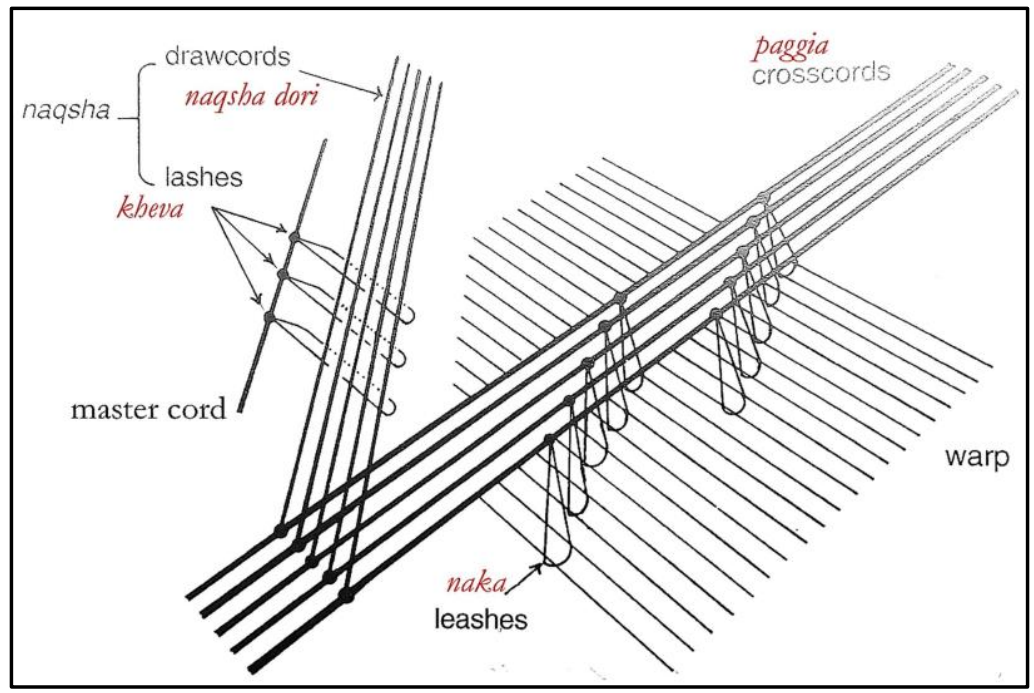

Fig. 22 Naqsha diagram, after R. Jain, Textile Museum Journal (1993-94).

As a scholar, I know full well that questions lead to more questions, and the more I learn, the more I realize there is to learn. Many questions were raised in our traveling seminar, and many more remain unanswered. But our group endeavor greatly enlarged my understanding of textiles and architecture, and the advanced and complex technology of drawloom weaving. 


\section{Historical Textiles in Museum Collections \\ Louise W. Mackie and Anna Jolly}

Anna Jolly: On our first day in New Delhi, we visited the National Museum. We spent the entire day at the Department of Central Asian Art, where curator Dr. Binoy Kumar Sahay very kindly received us (fig. 23).

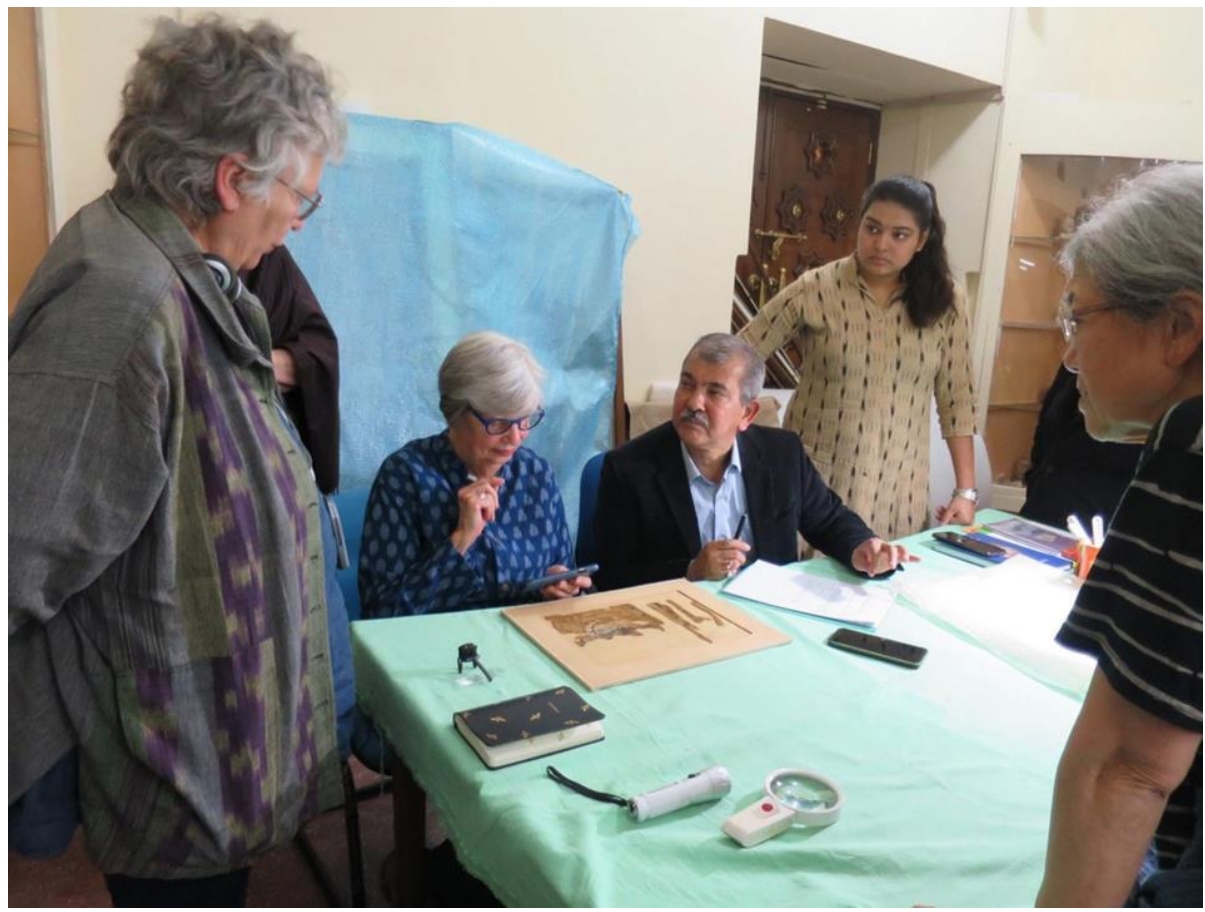

Fig. 23 Study session with Dr. Binoy Kumar Sahay, Curator of the Central Asian Department, National Museum, New Delhi. Photo: Anna Jolly, 2020

He permitted us to study a range of textiles from the Collection of Sir Aurel Stein that had been found in Astana in western China in the early twentieth century. Carol Bier, who many years ago had studied the textiles from the Stein Collection in New Delhi had compiled a selection of pieces that would be of interest to us and had submitted this request-list to Dr. Sahay in advance of our visit. Most of the textiles from the Aurel Stein Collection that are preserved in the National Museum have recently been published in an article by Binoy Kumar Sahay with photographs and detailed technical analyses in a new publication of the National Museum. ${ }^{15}$

It was wonderful to see textiles of various origins and dates and made in various techniques, ranging from silk weavings, embroidered or tapestry woven textiles to resist dyed silk fabrics. We saw a Sasanian silk fragment showing a boar's head and a Sogdian silk weaving with a motif that was difficult to interpret. Another treat was a fine tapestry weaving showing the head of Hermes with his staff, that must have originated in the Eastern Mediterranean around the fourth century C.E. and later travelled along the silk road to western China (fig. 24). ${ }^{15}$ Binoy Kumar Sahay, “Technical Studies of Central Asian Textiles,” B. R. Mani, Anamika Pathak (eds.), Textiles-
Binding Threads between Cultures from National Museum Collections (New Delhi: National Museum, 2019), 74-91. 

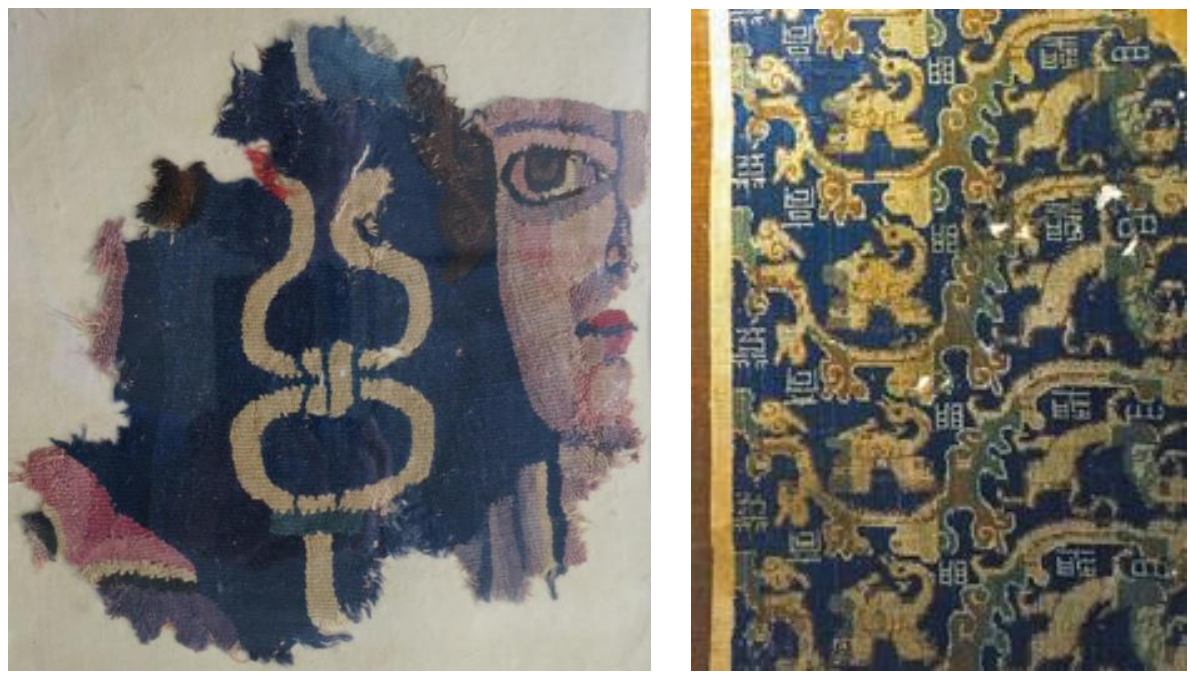

Fig. 24 Tapestry weaving with the head of Hermes, $3^{\text {rd }}-4^{\text {th }}$ century C.E., National Museum, New Delhi.

Fig. 25 Warp patterned woven silk, China, 1st-2nd century C.E., National Museum, New Delhi, detail. Photos: after B.R. Mani, Anamika Pathak (eds.), Textiles - Binding Threads between Cultures from National Museum Collections, $2019,84,89$.

While we had been waiting for our appointment in the gallery of Central Asian Art, we had time to admire a warp patterned silk weaving with woven inscriptions from the time of the Han dynasty (fig. 25) as well as a charming resist dyed silk with bird motifs from the Tang period. A couple of days later we went to the National Museum again to visit the Department of Decorative Arts, where we studied several later textiles.
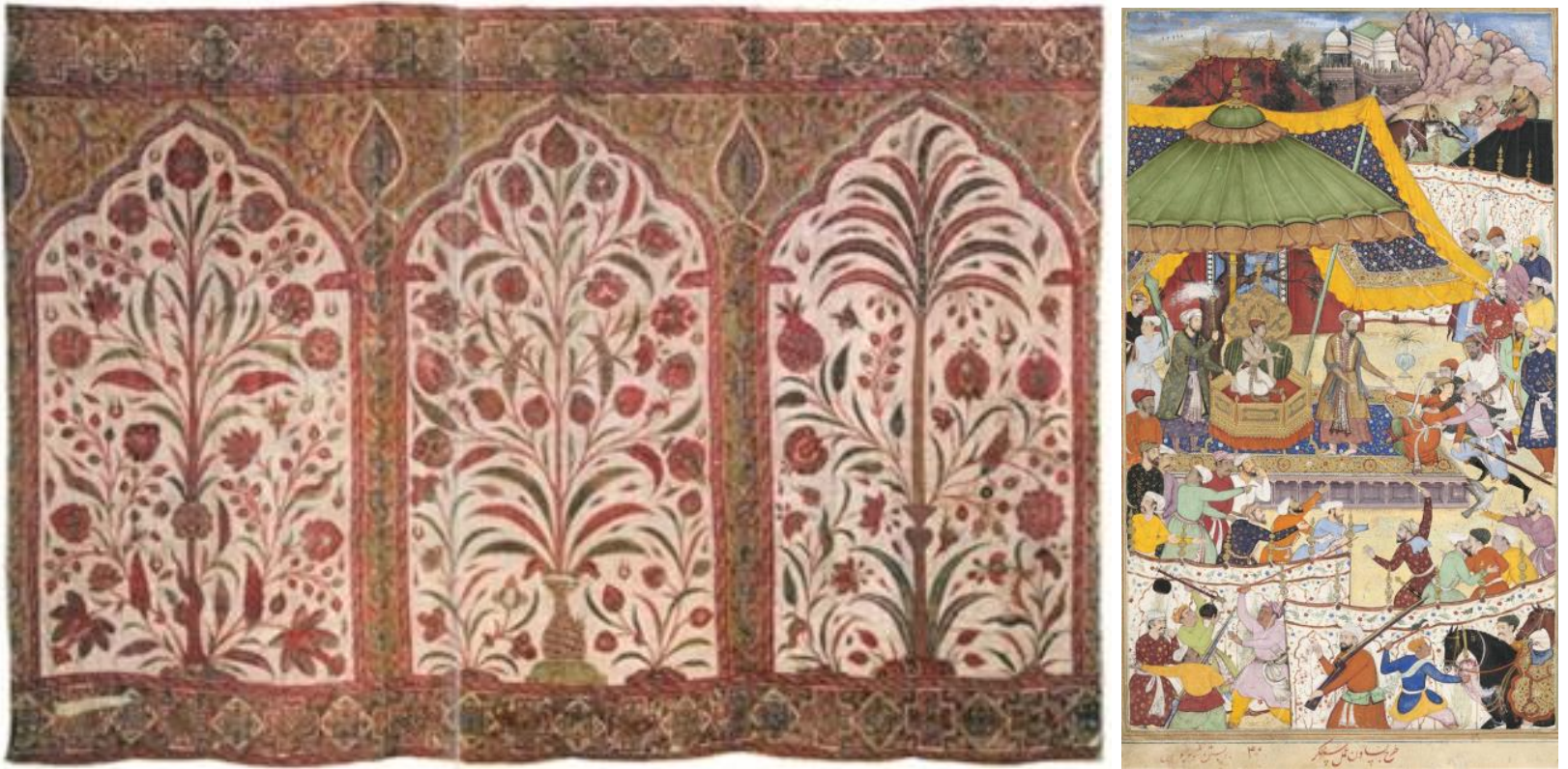

Fig. 26 Tent Wall Panels, cotton, hand draw resist and mordants. India, before 1645. National Museum, New Delhi, acc. no. 74.68. Photo: after Rahul Jain, Rapture. The Art of Indian Textiles, 2011, 92-93. Fig. 27 Emperor Akbar arrests an Insolent, India, 159095, The Art Institute of Chicago, 1919-898. Photo: bpk / The Art Institute of Chicago / Art Resource, NY

Louise W. Mackie: Deputy Curator, Dr. Zahri 'Ali Ansari, showed us some brightly colored cotton fabrics, India being an ancient cotton culture where pioneering, colorfast dye technology had been developed by around 1600 which led to extensive international export trade. 
This cotton arcade displays vibrant blossoming palm-like trees made in laborious techniques involving hand-drawn resist and mordant dye, often called chintz (fig. 26). They formed the interior wall panels, or qanat, from a set of nine, of a royal Rajput tent enlivened with colorful flora adapted from nature (fig. 27). Rulers owned many palatial decorative tents that were pitched precisely in city-size encamplements for resting during frequent military, political, and pleasurable travels. These panels survived with an inventory tag dated 1645 in the Amber Palace in Jaipur.

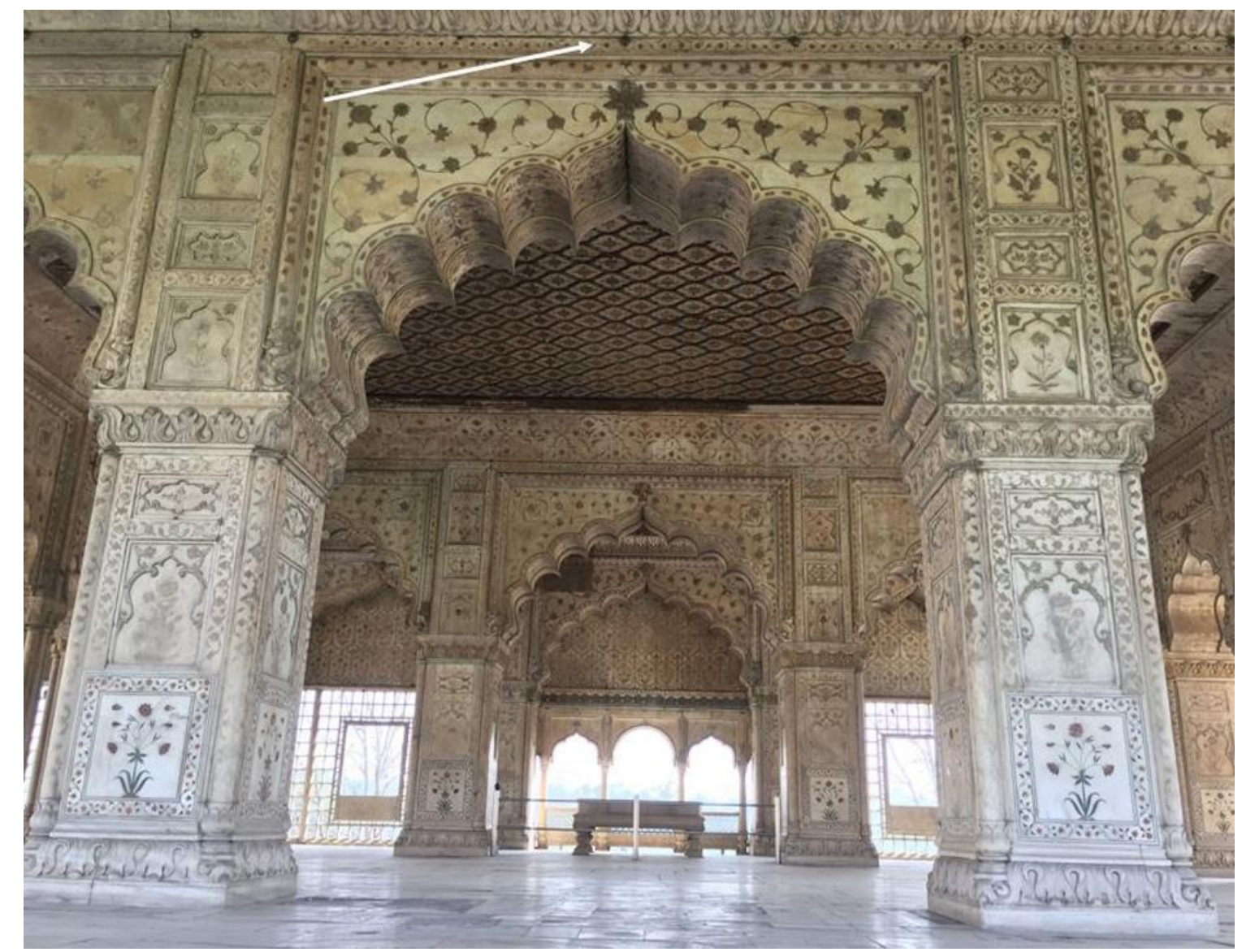

Fig. 28 Shah Jahan's Hall of Private Audience, 1639-1648, Red Fort, New Delhi, front view. Photo: Anna Jolly, 2020

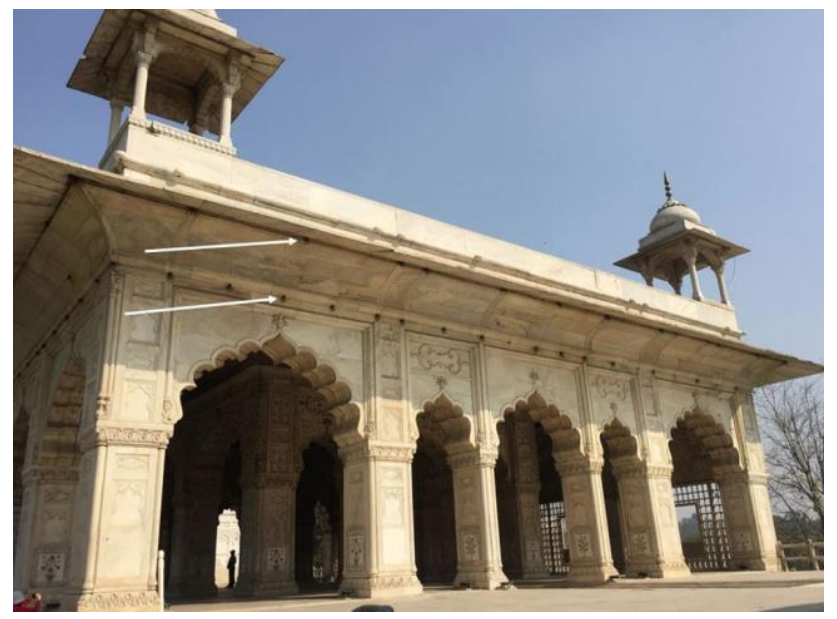

Fig. 29 Side view (arrows point to rings for hanging textiles). Photo: Anna Jolly, 2020 
Emperor Shah Jahan built the Red Fort (Shahjahanabad, 1639-48) in Delhi as his primary residence with three white marble-clad pavilions for public and private audiences. They were open on all four sides to walled four-part riverfront gardens (chahar bagh), discussed below (figs. 40-42). Exquisite floral decoration inlaid with fine pietra dura convey eternal paradisiacal blooms. Blossoming flora and plants were Shah Jahan's signature motifs, influenced by European botanicals adapted as imaginary plants and hybrids bearing everlasting flora associated with Paradise. In this exceptional setting, I became very excited when I noticed the metal rings across the top of the wall for textile hangings, and a second set of metal rings under the eaves for textile awnings (figs. 28-29).

This watercolor illustrates the same Private Audience Hall, fully rigged, showing preparations for Emperor Akbar Shah's departure in 1817 (fig. 30a-b). It suggests how Shah Jahan might have used the pavilion, also with imperial red tents, their exclusive color, but luxurious "red velvet, embroidered with gold," according to Jean-Baptiste Tavernier. ${ }^{16}$ The full view of the tentage shows weights securing the awnings in the foreground; the detail reveals lower portions of large textile hangings. It also illustrates the pulley system for a huge hanging, and a raised door panel in the middle of qanat panels that connect with the adjacent hammam building with steam baths.

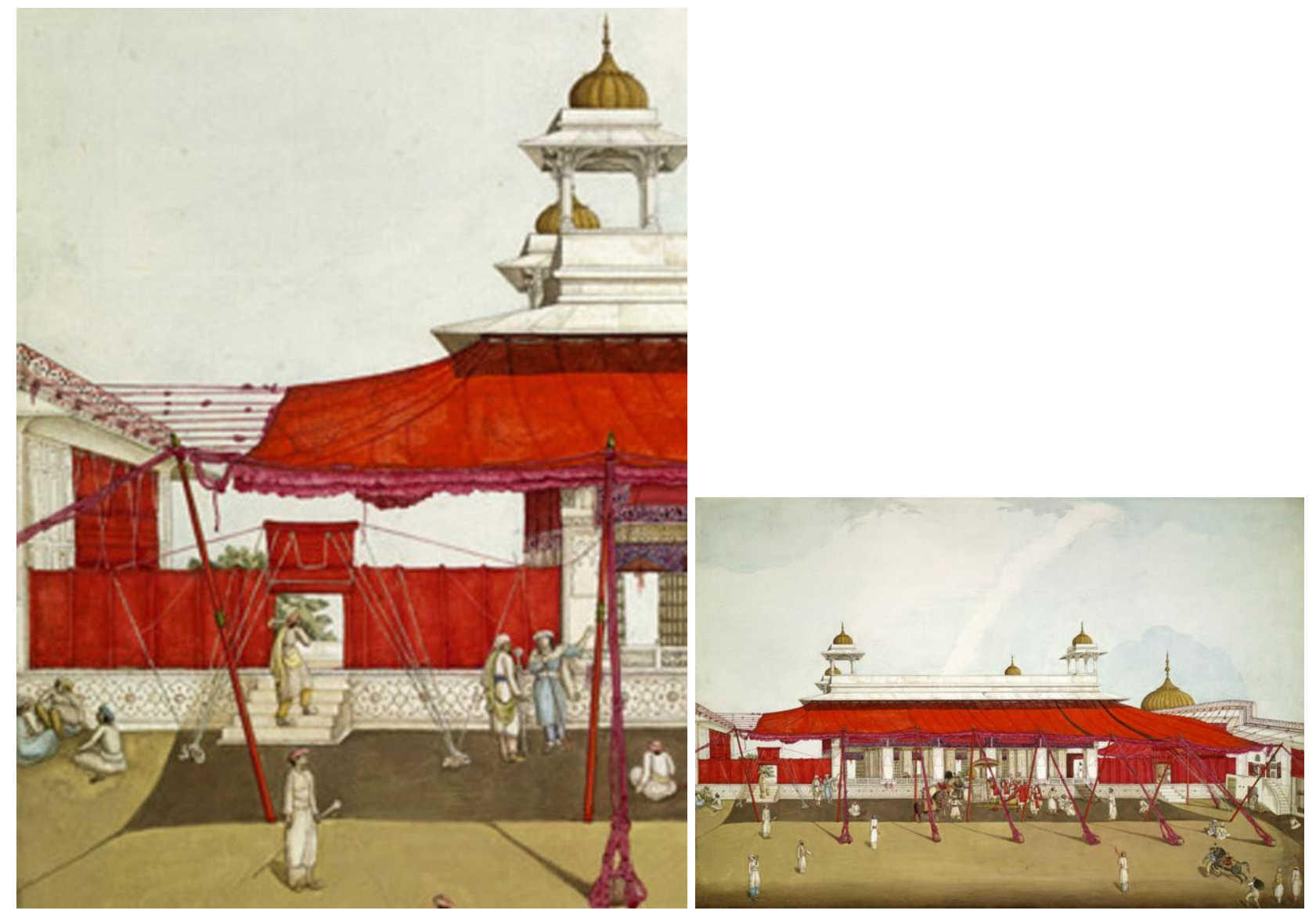

Fig. 30a-b Red Fort, New Delhi, Hall of Private Audience, 1639-1648, Painting attributed to Ghulam 'Ali Khan, 1817. British Library, Add Or 4694, London. http://www.bl.uk/onlinegallery/onlineex/apac/addorimss/t/largeimage55094.html

${ }^{16}$ Jean-Baptiste Tavernier, Travels in India by Jean-Baptiste Tavernier, trans. V. Ball (London, New York: Macmillan, 1889), 1, 380. 
In 1949, the Calico Museum of Textiles was founded in Ahmedabad by Gira Sarabhai, who comes from a wealthy philanthropic family. The museum has the foremost textile collection in India and displays over 1000 textiles in densely displayed galleries where an excellent guide inspired us to consider their broad cultural and spiritual significance as well as artistic and technical features.

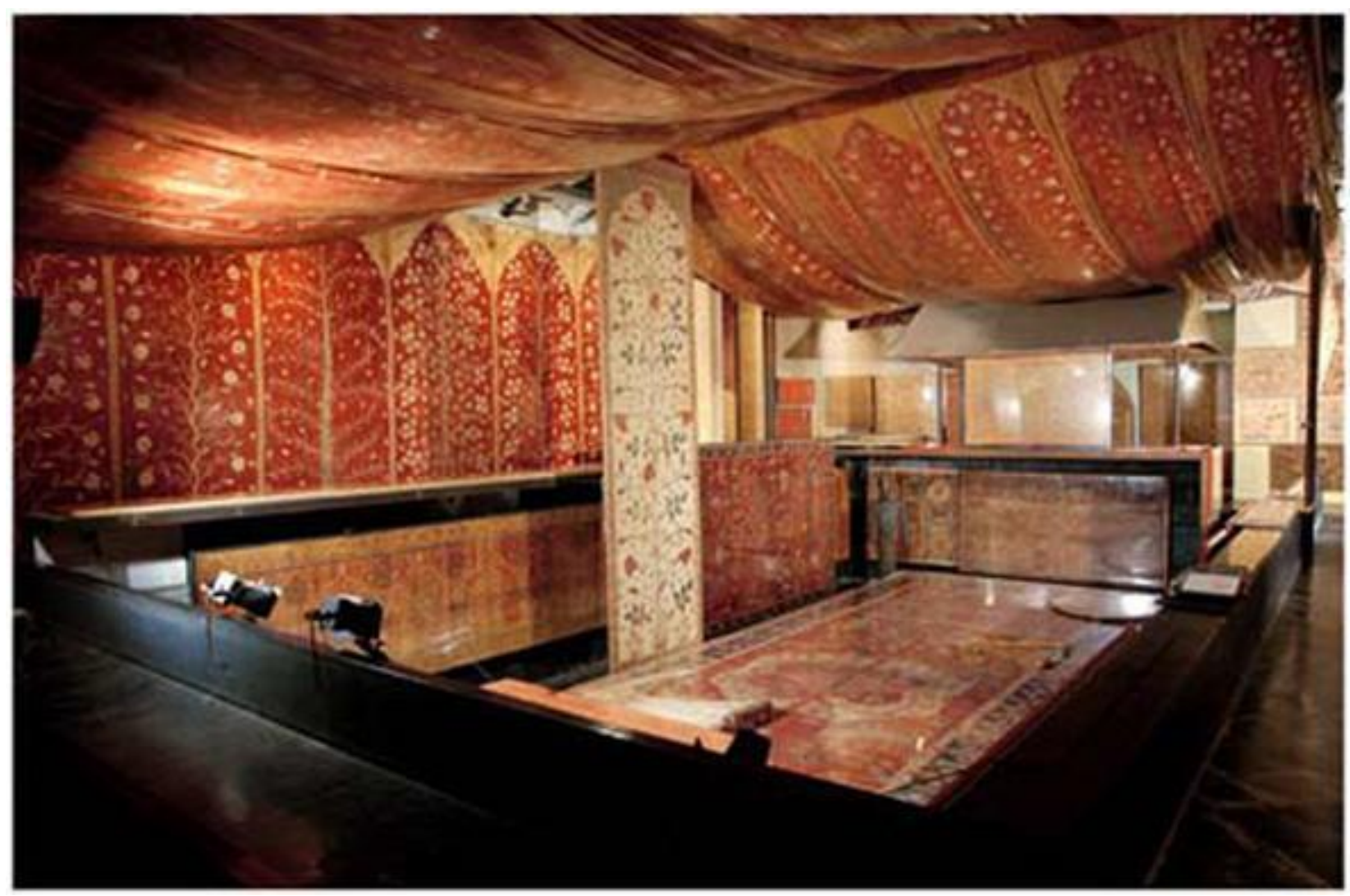

Fig. 31 Calico Museum of Textiles, Ahmedabad, Gallery of Mughal court textiles, roof and wall panels, printed and painted cotton https://www.calicomuseum.org/visiting-the-museum-galleries

A huge cotton tent ceiling, c. $750 \mathrm{~cm}$ or $25 \mathrm{ft}$ in length, with matching early nineteenth century wall panels is mounted on the ceiling of the main gallery of Mughal court textiles (fig. 31). ${ }^{17}$ There, we also saw luxurious Mughal silks. In the late 1500s, Emperor Akbar increased the quality and prestige of silk fabrics by hiring foreign masters, many from Iran, to train Indian workers, according to Abu'l Fazl's history, $\bar{A}$ 'in-i Akbarī. ${ }^{18}$

\footnotetext{
${ }^{17}$ Peter Alford Andrews, Tentage at the Calico Museum and its Patterns (Ahmedabad: Sarabhai Foundation, 2015), $218-237$.

${ }^{18}$ Abu'l Fazl Allāmī, The Ā'in-i Akbarī (Calcutta: [Royal] Asiatic Society of Bengal, 1939), vol. 1, 93-94.
} 

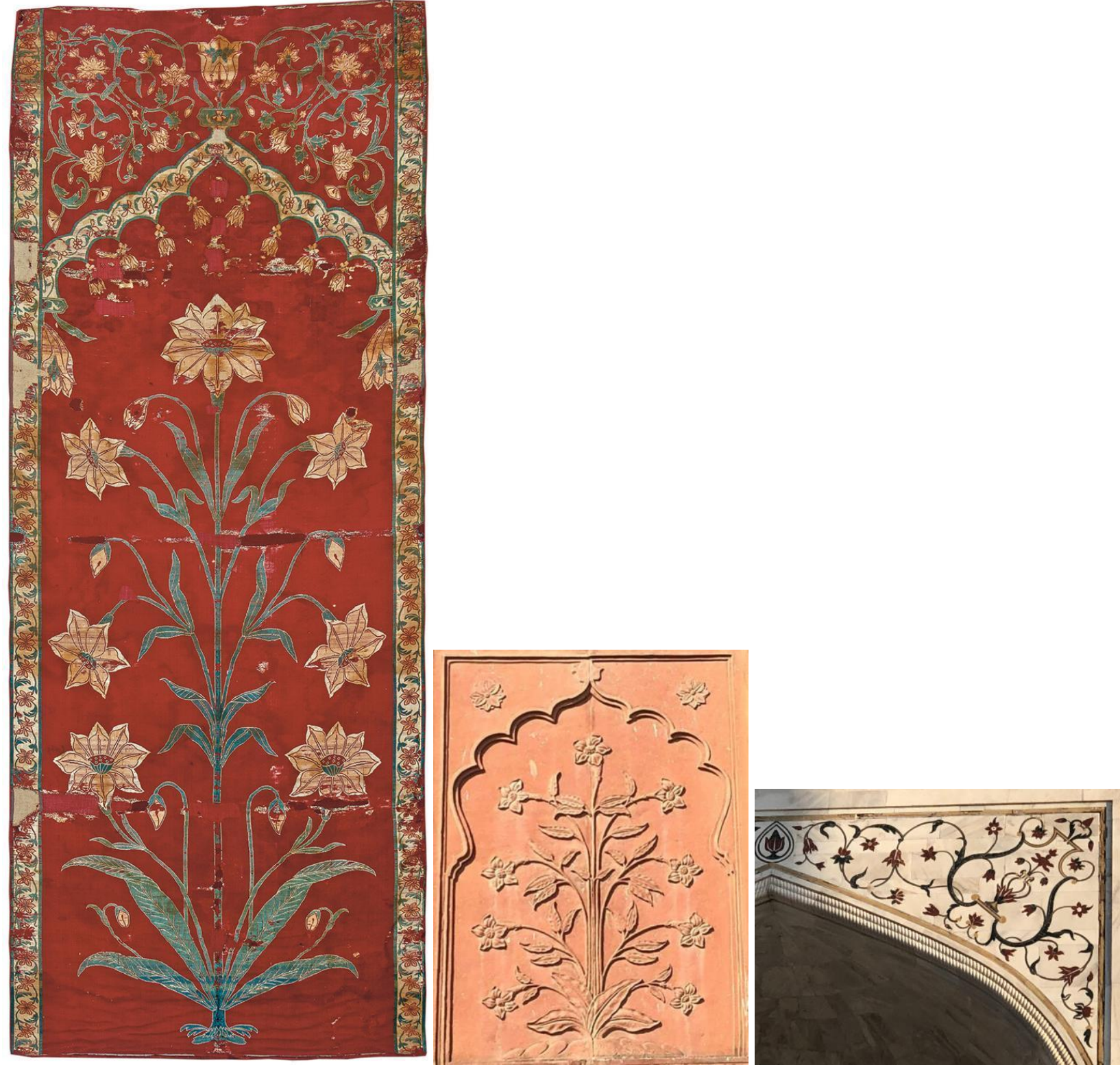

Fig. 32 Tent panel (qanat), lampas, $229 \times 99$ cm, India, mid-17th century, Calico Museum of Textiles, Ahmedabad, acc. no. 328.

Photo: Courtesy Sarabhai Foundation-Calico Museum of Textiles. Fig. 33 (center) Sandstone carving, mid-17th century, gate inside the Red Fort, New Delhi. Fig. 34 Pietra dura inlay on the façade of the Taj Mahal, Agra, completed 1648. Photos: Anna Jolly, 2020

Anna Jolly: One of the silk textiles that we saw in the Calico Museum in Ahmedabad was a spectacular mid-seventeenth-century lampas weaving, that may originally have served as a tent panel (fig. 32). ${ }^{19}$ This 7.5 feet long panel was woven in one piece. Its pattern shows a monumental single flower motif underneath an arch that is adorned with scrolling flowers. The blossoms of the plant, which resembles a lily, are shown at various stages of their development from bud to full bloom. Very few silk weavings with single flower motifs are known to have survived from the seventeenth century; some of them were even woven in velvet.

\footnotetext{
${ }^{19}$ Lampas is a compound, figured flat weave. It consists of a ground or foundation weave formed by a main warp and a main weft; supplementary wefts float on the surface as required by the design, and are bound by a binding warp. Foundation and supplementary weaves can be tabby, twill or satin.
} 
The composition of the lampas panel is symmetrical and shows a vertical point repeat, including the lateral borders with their motif of scrolling flowers. Its red ground was woven in a 5-end satin weave, the pattern wefts are bound by a binding warp in twill. ${ }^{20}$ The height of the design comprises the entire length of the panel. This is an extremely high pattern repeat. Usually, the height of the technical pattern-repeat of Indian silk weavings is much smaller. In order to weave such a high repeat on a traditional Indian drawloom, the design would have had to be split into several sections, and their respective weaving programs prepared in advance in the form of individual naqshas for each section of the composition. These would then be mounted onto the loom one after the other to weave the entire length.

As Louise noted, flowers were the favorite motifs of Shah Jahan. We saw comparable flower motifs in the buildings that had been commissioned by Shah Jahan in the mid-seventeenth century. Examples are some of the flower motifs under arches that were carved in red sandstone and partially gilt on the garden façade of the gate leading into the Red Fort (fig. 33). The flowering scrolls in pietra dura inlay on the façade of the Taj Mahal (fig. 34) recall the flowering scrolls in the spandrels of the above lampas tent panel. In most cases the flowers that are represented in Mughal architecture and other works of applied art are botanically not identifiable. Rather than being portraits of nature, they are works of art inspired by nature. ${ }^{21}$
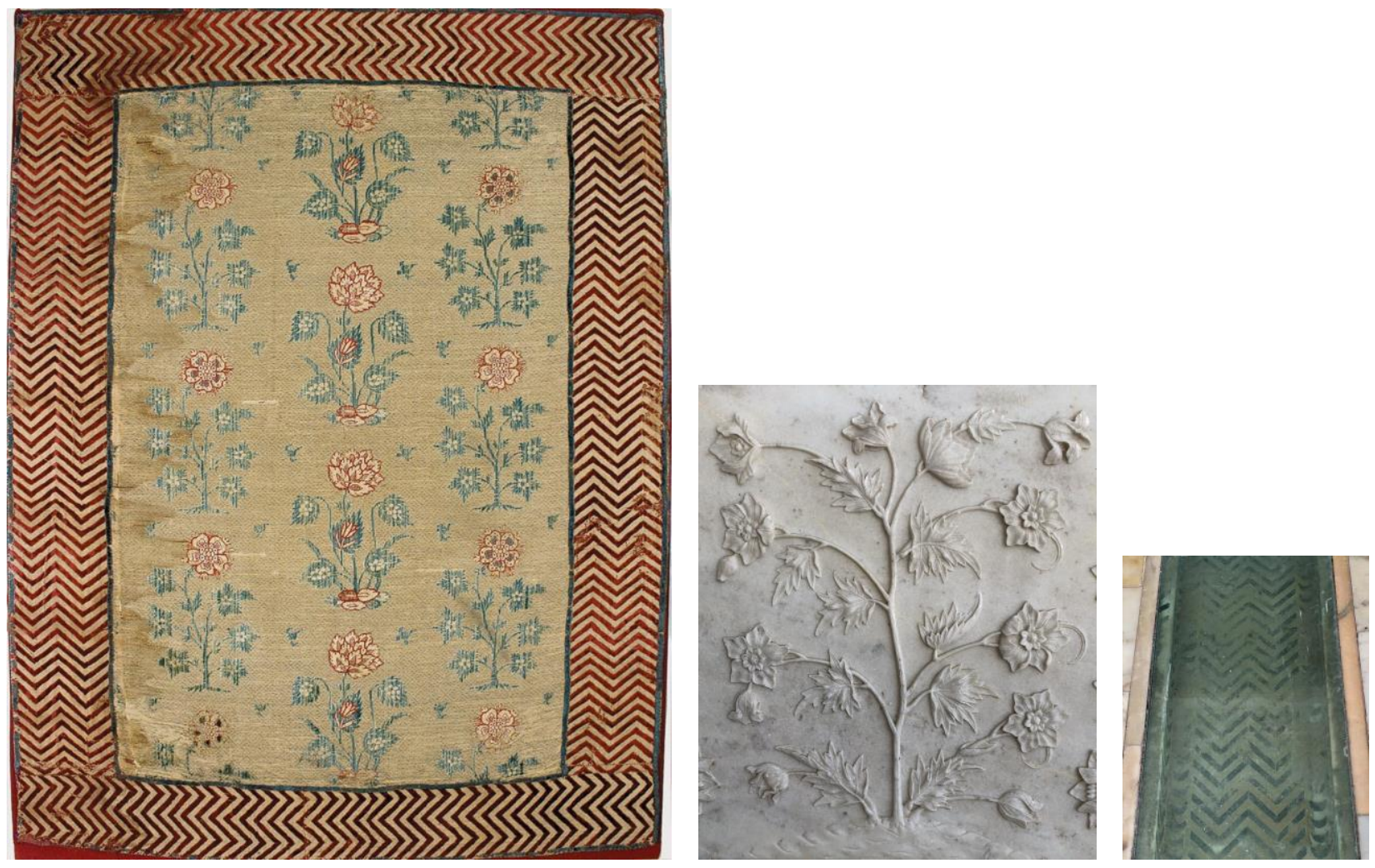

Fig. 35 Silk velvet panel, India, 1650-1700, Calico Museum of Textiles, Ahmedabad, acc. no. 17. Photo: Courtesy Sarabhai Foundation-Calico Museum of Textiles. Fig. 36 (center) Marble relief on façade of the Taj Mahal, Agra. Photo: Anna Jolly, 2020. Fig. 37 Water channel with chevron pattern marble inlay, Jaipur, Amber Fort, Summer Palace. Photo: Louise W. Mackie, 2020

\footnotetext{
${ }^{20}$ Rahul Jain, Indian Lampas Weave Silks in the Collection of the Calico Museum of Textiles (Woven Textiles. Technical Studies Monograph No. 3) (Ahmedabad: Sarabhai Foundation, 2013), 36-37.

${ }^{21}$ Ebba Koch, The Complete Taj Mahal and Riverfront Gardens of Agra (London: Thames \& Hudson, 2006), $218-219$.
} 
The main gallery of the Calico Museum also contains a group of superb Mughal velvet panels, that we were kindly permitted to study in the presence of Nigar Gajjar. The panel above with flower motifs and a gold ground as well as an attached border with a red chevron pattern is an example (fig. 35). The central velvet panel shows two different flower motifs in offset rows, all facing the same direction. This is a characteristic of Indian textiles as opposed to Iranian textiles, where motifs usually change direction from one horizontal row to the next. ${ }^{22}$ The flowers in this textile are woven with a silk pile of three different colours, whereas the ground is covered with silver gilt facing wefts. ${ }^{23} \mathrm{We}$ saw similar flower motifs on historical monuments such as the marble reliefs that may be admired on the walls next to the entrance of the main mausoleum of the Taj Mahal (fig. 36). These show similar multi-layered blossoms and leaves with serrated edges.

Mughal velvet panels were typically surrounded by separately woven borders that usually show a different pattern complementing that of the main field. The border of the velvet panel shown above may actually be an addition of the late eighteenth or nineteenth century, which replaces an earlier border. But zigzag patterns had been popular in Indian culture since the seventeenth century, not only in the Mughal Empire, but also in the state of the Rajput rulers in Rajasthan. A water channel in the summer palace of Amber Fort in Jaipur, for instance, shows zigzag marble inlay (fig. 37).

High quality silk velvet, especially when including gold and silver thread, has always been among the most luxurious woven textiles in any culture. Whether in Europe or Near Eastern regions such as the Ottoman, the Iranian or the Indian empires, velvet required a most labor-intensive weaving process as well as a far greater amount of warp material than flat weaves, in order to produce the velvet pile. Hence the use of velvet for interior decorations or as clothing material was in historical times largely reserved to the ruling classes.

The Calico Museum has been exemplary in publishing their textile holdings. Their numerous catalogues include a recent series of monographs with technical studies by Rahul Jain on specific groups of textiles, such as lampas and velvet weavings, with detailed technical analyses and very helpful thread models illustrating the weave structures. ${ }^{24}$ The technique of velvet weaving was probably brought by Iranian weavers to Mughal India. However, Indian weavers slightly changed the set-up of the velvet looms, for instance whereas Iranian velvets usually contain four ground wefts, two of which hold the pile warp from the back and the front, Indian velvets only contain three ground wefts, one of which holds the pile warp from the back. ${ }^{25}$

Louise W. Mackie: An outstanding textile collection featuring Mughal and Kashmir sashes and shawls is housed in the Bharat Kala Bhavan, the University Museum of Banaras Hindu University in Varanasi, second only to the Calico Museum, and curated by Dr. Priyanka Chandra.

\footnotetext{
${ }^{22}$ This difference between Iranian and Indian textile design is noted by Rahul Jain, "The Indian Drawloom and its Products," The Textile Museum Journal, 32-33 (1993-1994), 50-81, see 60-61.

${ }^{23}$ Rahul Jain, Mughal Velvets in the Collection of the Calico Museum of Textiles (Woven Technical Studies Monograph No. 2) (Ahmedabad: Sarabhai Foundation, 2011), 53-59.

${ }^{24}$ Jain, Mughal Velvets, 14-15. Jain, Indian Lampas Weave Silks, 10-11.

${ }^{25}$ Jain, Mughal Velvets, 9-17, discusses technical differences among Safavid, Ottoman and Mughal velvets.
} 

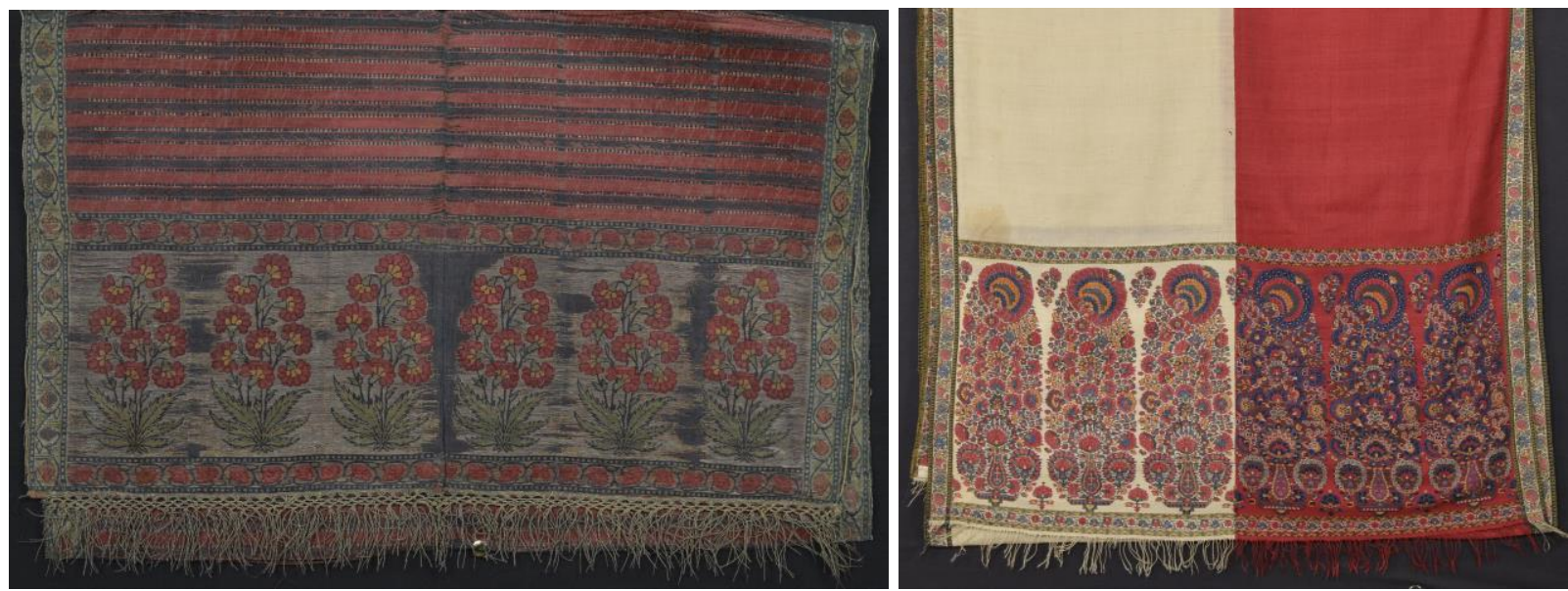

Fig. 38 Sash (patka), India, attributed to Shah Jahan (1650-75), detail, gilt-metal, silver-metal \& silk thread, compound weaves, Bharat Kala Bhavan, Varanasi, no. 3/9930. Fig. 39 Sash (patka), India, Kashmir, ca. 1770-80, detail, pashmina, double-interlocked twill tapestry, Bharat Kala Bhavan, Varanasi, no. 3/8590. Photos: Courtesy of Bharat Kala Bhavan

A lavish sash, or patka, attributed to Shah Jahan with his favored floral decoration illustrates sophisticated artistic and technical refinement (fig. 38). It was woven in three different compound structures, each according to its function, in the field, side borders and end panels (pallaka). Rahul Jain describes this rare multi-structure expertise as "tailored on the loom," which also characterizes the Textile Museum sash that changed his life (fig. 3). Originally, the finest Mughal silks with giltmetal thread were as brilliant and colorful as Jain's ASHA patka (fig. 4), based on depictions in paintings and the pristine condition of Mughal velvets in the Topkap1 Palace in Istanbul. ${ }^{26}$

A century later, a royal patka woven in Kashmir with pashmina, the finest goat hair, in doubleinterlocked twill tapestry displays a rare two-color field (fig. 39). Worn folded lengthwise around the waist, only one color was visible, increasing its use. The floral end panels, or pallaka, were draped in front to show off the prestigious floral botehs, or buta (fig. 27), motifs often called "paisley" in English after their fashionable nineteenth-century production in Paisley, Scotland.

We were delighted to see the magnificent, renowned Garden Carpet in the Albert Hall Museum in Jaipur (figs. 17, 40). It displays a paradisiacal chahar bagh (fig. 41b), a four-garden plan from fifteenth-century Timurid Iran and Central Asia which the Mughals adapted and Shah Jahan elevated with perfect symmetry for the Taj Mahal setting in Agra (figs. 42a,b). In addition since Timurid chahar bagh gardens have not survived, this singular carpet contributes a visual image to the literary and archaeological evidence.

This large carpet was woven in Kirman, Iran, around 1600, based on its vibrant colors and technique with cotton warp, cotton, wool and silk weft, silk used in the best quality, and ca. 4,700 asymmetrical wool knots $\mathrm{dm}^{2}$ (ca. 305/in $\left.{ }^{2}\right){ }^{27}$ It survived with an inventory label dated 1632 in an abandoned Maharaja's palace in the Amber Fort in Jaipur.

\footnotetext{
${ }^{26}$ Nurhan Atasoy, Walter B. Denny, Louise W. Mackie, and Hülya Tezcan, IPEK: Imperial Ottoman Silks and Velvets, comp. and ed. Julian Raby and Alison Effeny (London: Azimuth Editions on behalf of TEB Iletisim ve Yayıncılık, 2001), 16-18, fig. 8 .

${ }^{27}$ Bruce Healy, "The Jaipur Garden Carpet," Hali (March 30, 2020) https://hali.com/articles/the-jaipur-garden-carpet/ (accessed 24 December 2021).
} 
Vertical and horizontal watercourses intersect, with an elevated multi-story pavilion in the central pool, placing the owner in paradise with four rivers, as described in the Hadith (Traditions of the Prophet Muhammad), and Genesis 2:10-14. ${ }^{28}$ The walled garden pattern is essentially symmetrical along the central watercourse which reveals fish, waterfowl and land animals. The four-garden plan is composed of blocks of four squares with the same ground colors and vegetation, although their profiles vary as in nature, on each side of the carpet (fig. 40b), irrigated by subsidiary channels. The blocks are also bordered by colorful trees and flora of all seasons growing from wide, red-ground banks, a feature not adopted by the Mughals.
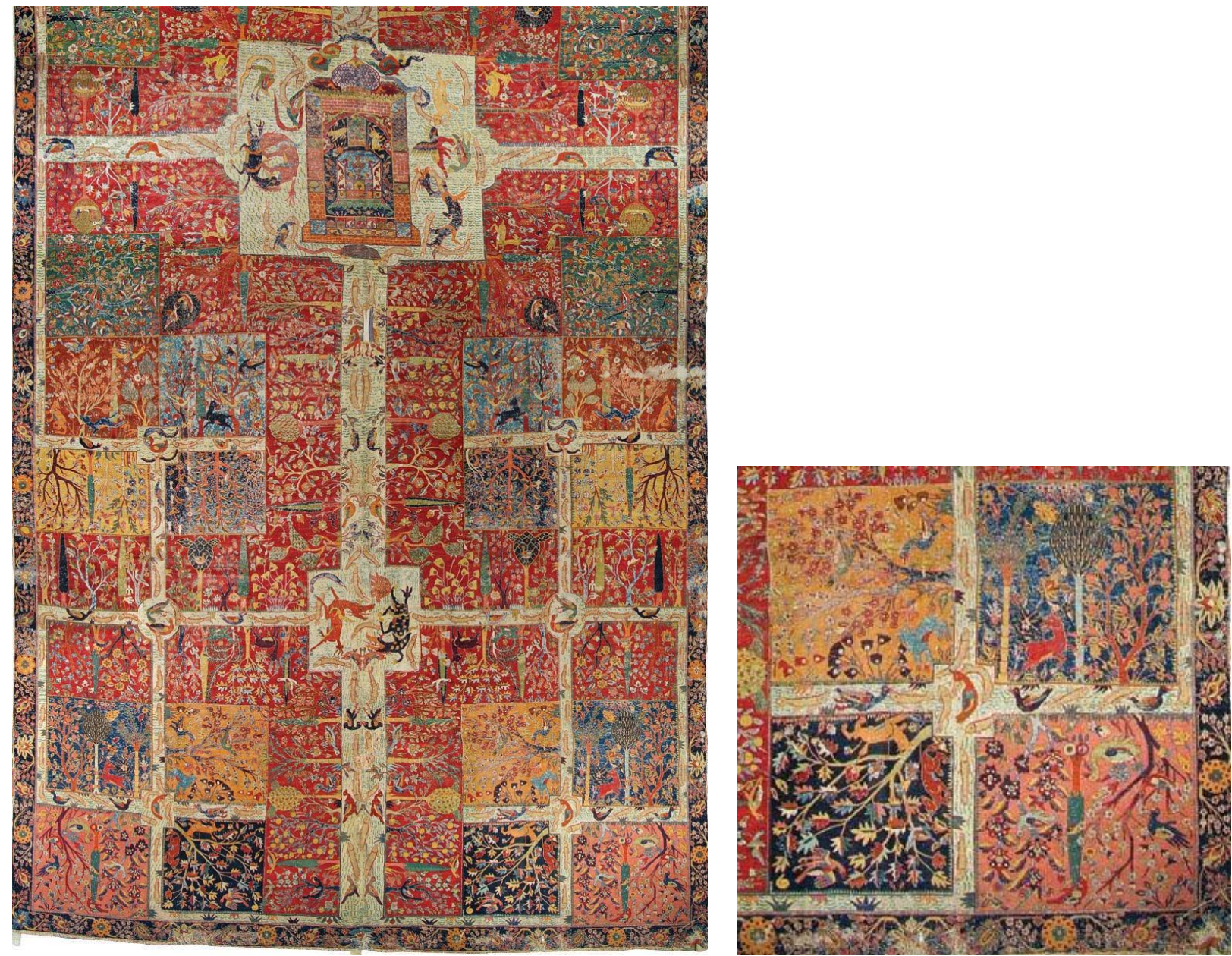

Fig. 40a Garden carpet, detail. Kirman, Iran, c. 1600, wool pile, c. 305 knots/in', 8.53 x 3.84 m (28'x 12'7'); Fig. 40b Four-garden (chahar bagh) detail ; Albert Hall Museum, Jaipur, no. 681/225. Photo: Government of Rajasthan Department of Archaeology and Museums/Mapin Publishing

\footnotetext{
${ }^{28}$ Lisa Golombek and Ebba Koch, "The Mughals, Uzbeks, and the Timurid Legacy," A Companion to Islamic Art and Architecture. Eds. F. B. Flood and G. Necipoğlu (New York: John Wiley \& Sons, 2017), 825.
} 


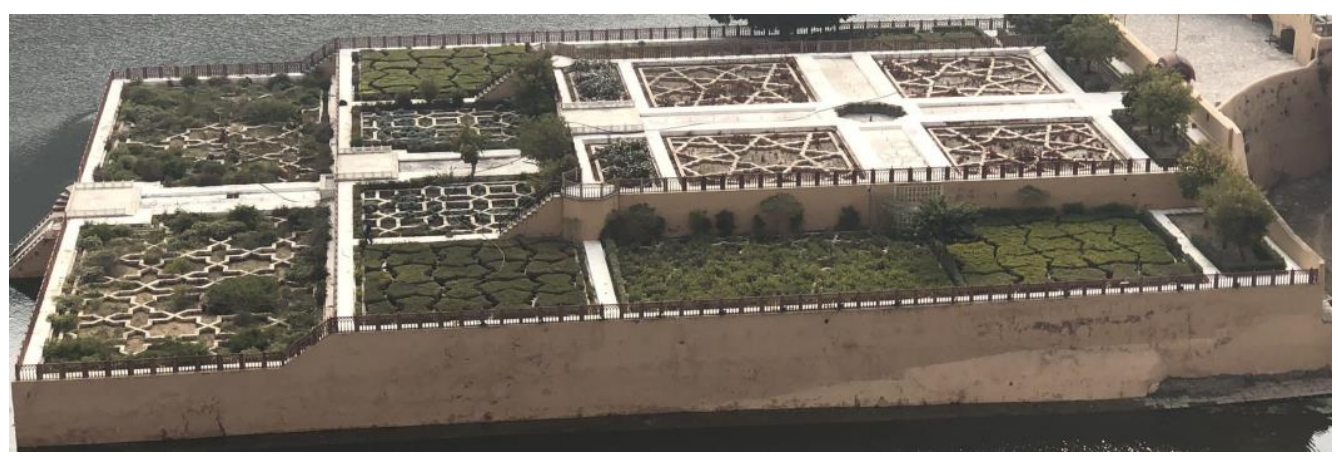

Fig. 41 Terraced four-garden plan (chahar bagh), Amber Fort, Jaipur. Photo: Anna Jolly, 2020

A striking terraced, four-garden plan, chahar bagh, enriched with star and geometric shapes of Timurid Iran origin, is visible beneath Amber Fort in the Yamuna River, one of the great holy rivers in India. They were introduced by Babur, founder of the Mughal dynasty, who in 1506 visited an Iranian chahar bagh garden estate in Herat, now in Afghanistan. ${ }^{29}$ Babur built the royal mausoleum for his son, Humayun (1569-70) in the center of a canonical cross-axial chahar bagh in Delhi. ${ }^{30}$
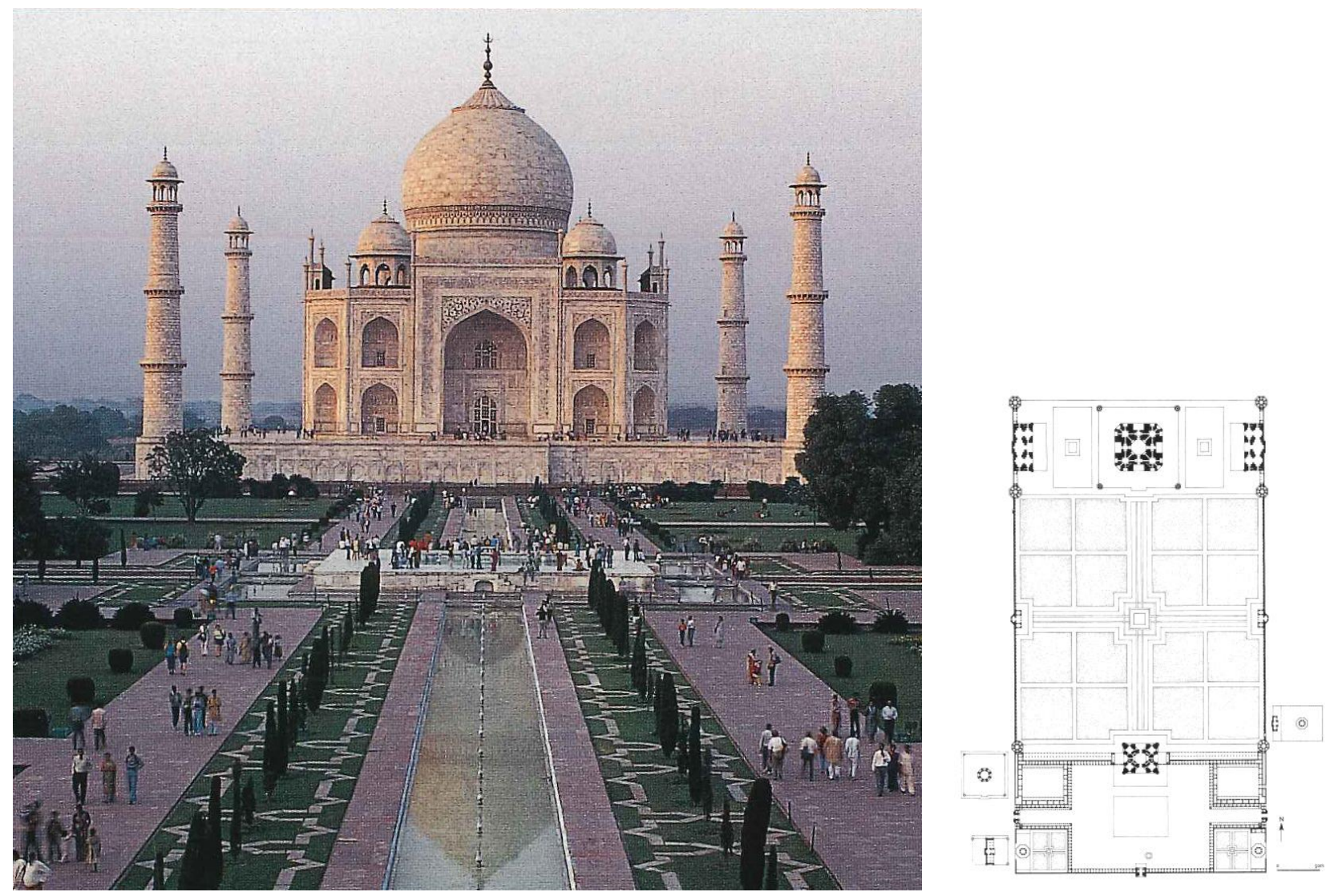

Fig. 42a Taj Mahal, Agra, 1632-43, completed 1648, built by Shah Jahan. Fig. 42b Plan of the Taj Mahal Complex with Terraced Four-Square Chahar Bagh Garden. Photos: after Ebba Koch, The Complete Taj Mahal and the Riverfront Gardens of Agra, $107,114$.

\footnotetext{
${ }^{29}$ Golombek and Koch, "The Mughals, Uzbeks, and the Timurid Legacy,” 825.

${ }^{30}$ For inscriptions comparing the gardens to Paradise, see Fatma Sadaf, "Gardens in Mughal India in the Light of Inscriptions," Proceedings of the Indian History Congress, vol. 74 (2013), 297-98. Indian History Congress http://www.jstor.org/stable/44158828 (accessed 14 January 2021).
} 
The most spectacular, riverfront four-part garden plan (chahar bagh) creates the paradisiacal setting of the Taj Mahal, built by Shah Jahan in memory of his beloved wife, Mumtaz Mahal, in 1632-43, completed 1648, in Agra, the beautiful, cosmopolitan Mughal capital (1556-1648) on the Yamuna River (fig.42a). Set on a raised platform at the end of the main watercourse, instead of in the center, the white marble-clad Taj Mahal radiates and reflects its ethereal majesty in the riverfront style chahar bagh preferred in Agra. Its perfect bilateral symmetry was one of Shah Jahan's architectural principles (fig. 42b). Quadrants divided into sub-quadrants with channels of flowing water abounded with a hierarchy of decorative flora, fragrant blossoming plants and fruit trees, some with funerary associations, that conveyed paradisiacal blooms as well as imperial propaganda. ${ }^{31}$

The Imperial Moonlight Garden (Bagh-i Mahtab Padshahi), later Moonlight Garden, located directly across the Yamuna River was designed as an integral part of the Taj Mahal complex. Built in the floodplain, it deteriorated until the Archaeological Survey of India began excavations in the 1990s. The center of the riverfront terrace retains remnants of a large octagonal pool with twenty-five fountains plus two pavilions and behind it, a classical chahar bagh with a pool. Vegetation believed used by the Mughals has been arranged by height from tall trees to small brightly-colors flowering plants, possibly originally intended to offer an ideal view of the ethereal Taj Mahal.

\section{The Indian Drawloom, the Naqsha and Velvet from a Weaver's Point of View Barbara Setsu Pickett}

The majority of my weaving experience has been on manual shaft looms used in home studios. My expertise with complex woven structures and patterning comes from designing and weaving velvets at the Fondazione Arte della Seta Lisio in Florence, Italy, on manual Jacquard 400 looms using a velvet bobbin rack with 800 pile bobbins. When I encountered Rahul Jain's velvet drawloom, it was overwhelming, a bewildering sea of fine silk threads and festoons of cordage. I was reminded that a loom is merely a device holding warps in tension, and each warp follows a specific pathway. I located the woven velvet on the loom and traced the warps back to their sources (fig. 43).

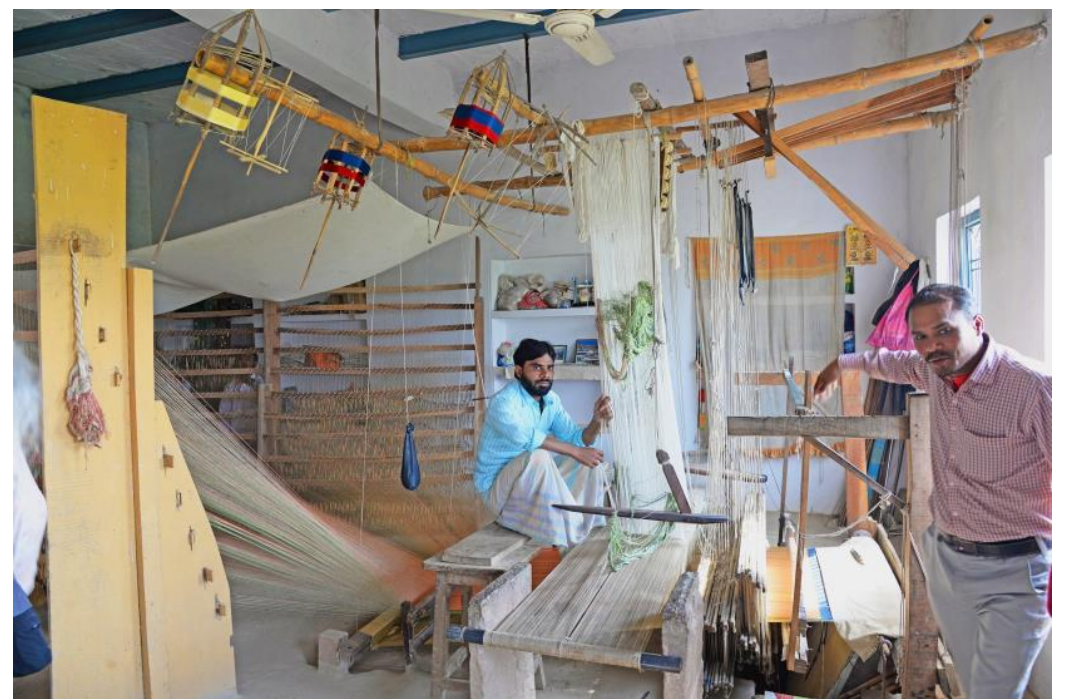

Fig. 43 Rahul Jain's reimagined Indian velvet drawloom. Photo: Barbara Setsu Pickett, 2020

${ }^{31}$ Koch, The Complete Taj Mahal, 217-19, 222-24, for the Moonlight Garden discussed below, see 56-57. 
The ground warp was firmly tensioned. Each ground warp went from the woven cloth back through a dent in the reed set in the beater. Each was threaded twice through heddles on different shafts, passed through the pattern harness and was wound onto a solid warp beam positioned close to the floor. The pile warp had a much longer, circuitous route. Every pile unit, wound on a separate bobbin and individually weighted, went from the woven cloth through a dent in the reed, passed through the bank of 21 shafts, was engaged in the pattern harness and sleyed through a second reed before dispersing to its precise position on a slat on one of four racks (fig. 43).

True looms have methods to make sheds. A shed is the space created when the warp divides into a plane above and below the crossing weft. The Indian drawloom has two shed-making systems that work in unison. A bank of shafts controlled by treadles govern the ground weave, and behind it, the pattern harness, a complex mass of knotted strings, rules the larger pattern design. A person perched on a board behind the pattern harness faces the masterweaver, takes his cues from him, and manipulates this harness to make the pattern sheds (fig. 43). In short, the shafts and treadles control the ground weave and the pattern harness, the naqsha, commands the pattern. The pattern is like the prima ballerina in the spotlight, the center of attention, while the ground is the corps de ballet, less conspicuously building the foundation and stability.

Indian shaft looms generally lack counterbalancing mechanisms to increase the height of the sheds. Instead they rely on pairing shafts, one rising and one sinking. The set of rising shafts are countered by the corresponding set of sinking shafts (fig. 44). The Indian heddle, bai, does not have an eye through which the warp passes, but a clasp of an upper and lower thread loop (fig. 45). The ground warp passes above the clasp on a rising shaft and below, on a sinking shaft. Each ground is threaded once above the clasp on a rising shaft and once below on a sinking shaft. The 21 shafts, the kandi, are organized from the reed back to the naqsha: three to sink the pile; five to sink the satin ground; three to raise the pile; five to raise the facing wefts; 5 to raise the satin ground. Shamim operates the seven treadles, called paori, two for the pile and five for the satin ground. When a satin treadle is suppressed, four shafts rise and one shaft sinks.
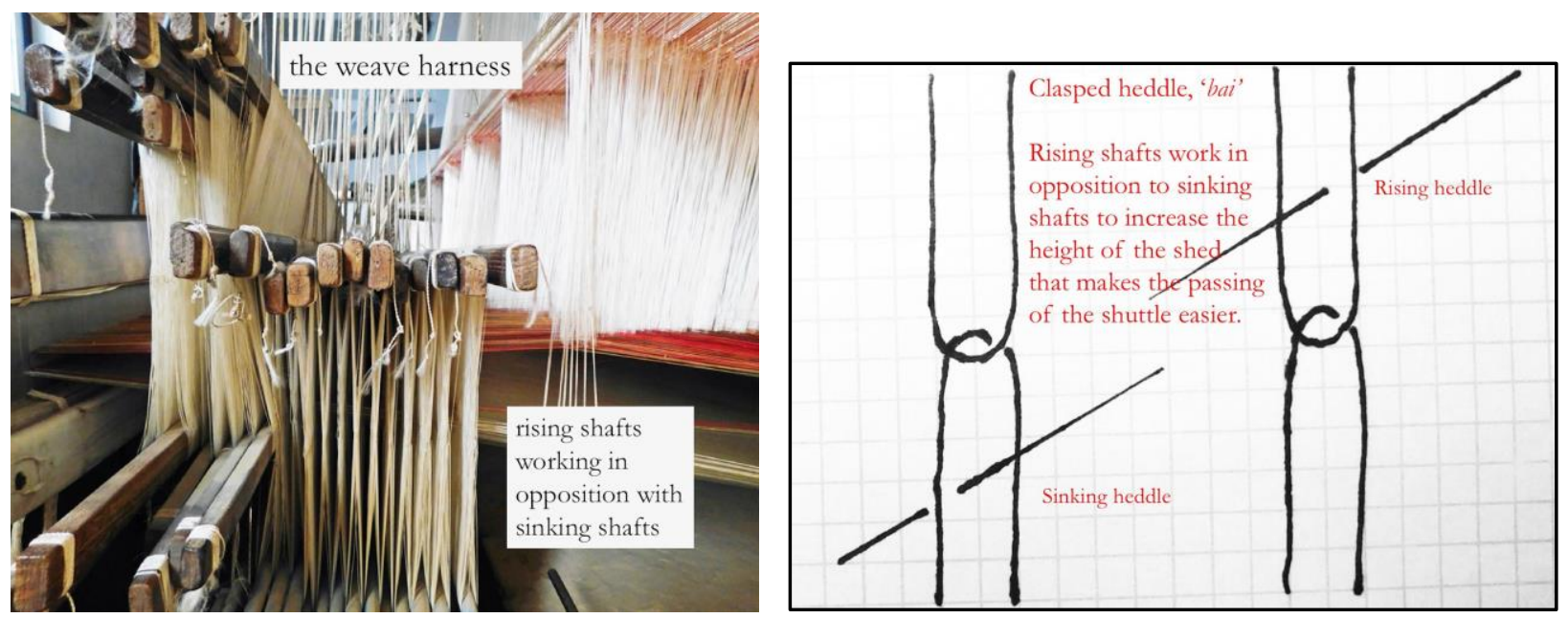

Fig. 44 Rising and sinking shafts in the weaving harness. Fig. 45 Illustration of the clasped heddle threading. Photo and illustration: Pickett, 2020

The pattern harness, the naqsha, is a marvel of efficiency and ingenuity. It has four components: the horizontal crosscords, the leashes that loop down from the crosscords and encircle a warp or 
several adjacent warps, the vertical drawcords that are knotted to the crosscords, and the lashes that loop through the drawcords making the selection for a particular pattern shed. To keep the correct sequence, each lash is knotted to a master cord, like beads on a string. In Varanasi, the crosscords are called the paggia; the leashes, the naka; the drawcords, the naqsha dori; the lashes, the kheva (fig. 46). When a pattern repeats four times across the width of the warp, four sets of naka leashes result (fig. 47). When the motif, like a medallion, has vertical bilateral symmetry, the naka leashes below the paggia crosscords have a center tie for each repeat, and then a leash on either side forms a triangular arrangement. Often a row of medallions is followed with an offset row, like brickwork.
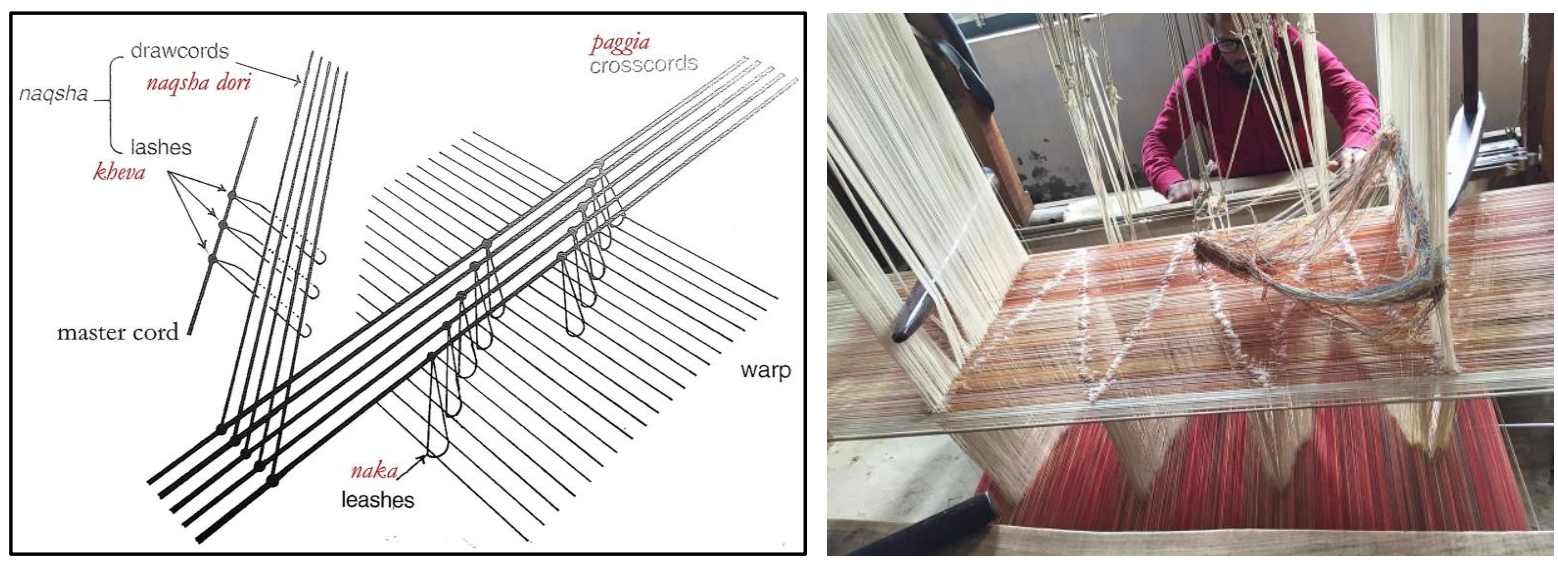

Fig. 46 Naqsha diagram, after R. Jain, Textile Museum Journal (1993-94). Fig. 47 The paggia with naka leashes. Photo: Louise W. Mackie, 2020

I must confess in 2016, my focus was so intent on learning the workings of the pattern harness that I had not a thought on how it was made or how it turned a design idea into the naqsha. When Rahul gently asked what I knew of the naqsha, I ashamedly admitted, I hadn't a clue. He arranged a visit to Naseem Ahmad, one of the last naqshband masters. That introduction made me realize how much more there was to learn. In this visit, the process became much clearer and I could finally link the making of the naqsha to the four components in the pattern harness. Carol was absolutely correct when she called the naqsha a bundle of logic. It looks like a mess, but it is a surprisingly efficient and economical system.

Naseem's equipment could not be simpler: a small wooden frame on legs, the machaan, and a bamboo pick. His supplies are heaps of sturdy cotton cordage. His expertise lies in applying his extensive knowledge of design and weave structure with his esthetics. To demonstrate he selected a single mango motif often called a paisley or boteh. Traditionally the design was etched full scale on a sheet of mica, an abhrak, but now it is usually drawn on a translucent, mylar-like paper. Then he calculated and played with the numerical proportions until he was satisfied. This step still mystifies me and more research would reveal the factors at play. This asymmetrical motif with no axis of reflection is like an island surrounded by ground weave. When a motif has a vertical axis of reflection, the draws can produce half of the motif and the leashes generate the mirrored half.

Naseem overlaid a grid on the motif and subdivided it into eight columns wide by seven rows high (fig. 48). Each column guides the selections for 12 vertical drawcords or a total of 98 naqsha dori for the whole motif. The number of drawcords determined the width of the design unit, the density of the warps, and the chosen pattern step. The sum of the rows reflects the total number of crosscords in the paggia. The quality of the line and the smoothness of the curves are at his 
discretion. Naseem said that his grandfather was renowned for his exquisite interpretations. His superb renderings were so distinctive that other naqshband could immediately identify his work. Naseem secured the 98 vertical drawcords, the naqsha dori, to the bar at the top of the frame, stretched and tensioned them on the bottom bar. To maintain the order, he twined across the top and bottom drawcords next to their bars, so that the drawcords lay flat, parallel and evenly spaced across the width. He blackened every $12^{\text {th }}$ drawcord to mark the eight columns in the grid. Using his bamboo pick, he threaded the first horizontal cord following the very bottom of the design motif. These horizontal cords become the set of lashes, the kheva. He marked every $16^{\text {th }}$ row to indicate each row in the seven-row high grid. The total number of lashes, 16 times seven equal 112 in lashes. To keep the correct order, each lash was attached to the two vertical master cords on the right side (fig. 49).
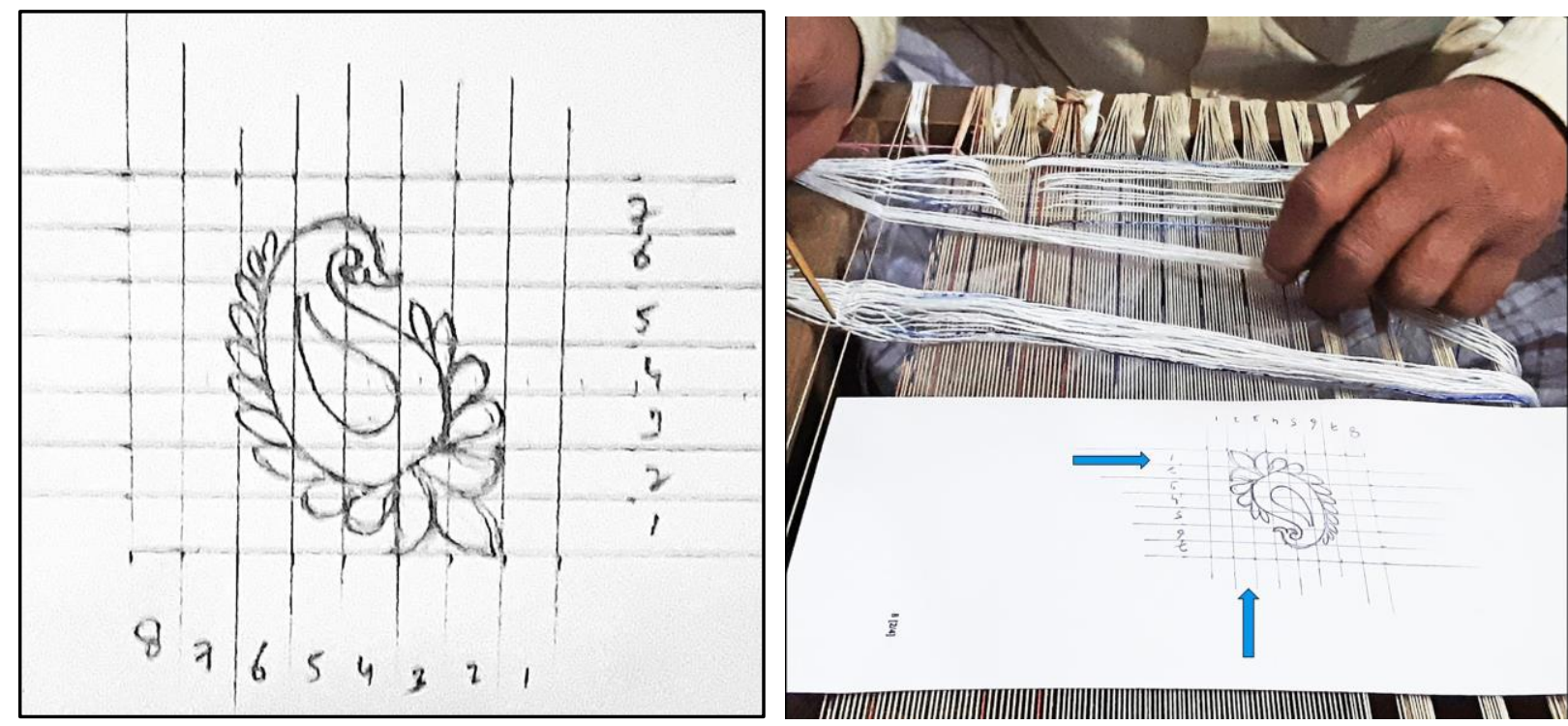

Fig. 48 Boteh motif with grid overlay. Fig. 49 Naseem Ahmad makes the naqsha. Photo: Pickett, 2020

Some consider Naseem the sole remaining naqshband in Varanasi. In 2008 he won a national award for his brocade artistry. His grandfather won a national award in 1973 and his great grandfather in 1965. The motif he chose to demonstrate for us was deliberately simple and quick. A record of him working at the top of his abilities would be a valuable archive. Naseem's son is often in the studio. It would be so gratifying if he could be the fifth generation to add to this legacy.

A quick comparison of the Jacquard and the naqsha shows several advantages of the latter. In Jacquard the repeat must adhere to the precise number of hooks in the head while the naqsha is not restricted; in Jacquard the comberboard dictates the width and density of the warp while the naqsha is free to vary; the Jacquard head is expensive and replacement parts are difficult to find or reengineer while the naqsha is a bundle of knotted string; in Jacquard, the lingos weigh down the pattern heddles while on the drawloom the downward slanting warps keep tension on the naka leashes and no space is needed beneath; the Jacquard cylinder can turn in reverse to correct mistakes, but works best rotating forward, while a draw person can pull the kheva lashes in reverse order, pivoting easily on a horizontal axis of reflection; the Jacquard is a heavy, noisy machine while the drawloom lends to a quiet working environment; storing a cumbersome Jacquard mounting takes a large crate, and the pattern cards are bulky and heavy while the naqsha is compact, portable, and lightweight, and would be easy to smuggle out of an atelier. Perhaps these 
traits led to the spread of the technology. Once textiles were at the cutting edge of technology, and the skill and knowledge to create them were coveted.

As Anna Jolly pointed out, velvet continues to be the most precious, prestigious cloth reserved for the highest echelons of society. It is the last of the great silk weaves to be created. It needs two sets of warps: the pile warp that makes the tufts and the ground warp for the foundation. Selected pile warps jump over a slim velvet wire and then get woven into the ground. After three velvet wires are woven in, the first can be safely removed. In polychrome velvets, at any point in the design there is a choice of color. The desired color makes the tuft while the other colors remain hidden. Rahul's velvet drawloom is a feat in experimental textile technology. It is unique, designed to handle these polychrome velvets. Other types of velvets and designs would breed different solutions.

The pile rack is organized into four banks, two on each side of a narrow aisle that provides access for repairs. Each bank has 10 slats with 350 pile units for each color, making 1,400 units for each color or a total of 4,200 pile units (fig. 50). The triad of piles closest to the left selvage comes from the highest slat on the left: the triad closest to the right selvage comes from the lowest slat on the right. A second reed placed on top of the ground warp beam maintains the pile's correct order. From there each pile unit finds its particular place on its slat. Each slat is drilled with 35 groups of three holes on a diagonal. A green pile passes through the top hole, a deep yellow through the middle hole, and a red through the bottom hole (fig. 51). Each unit is wound on its own pirn and dangles like a plumb bob with a 10-gram weight. Letting out more pile warp is done manually, often by Shafi Ulla, the father, patrolling behind the rack during the weaving process.
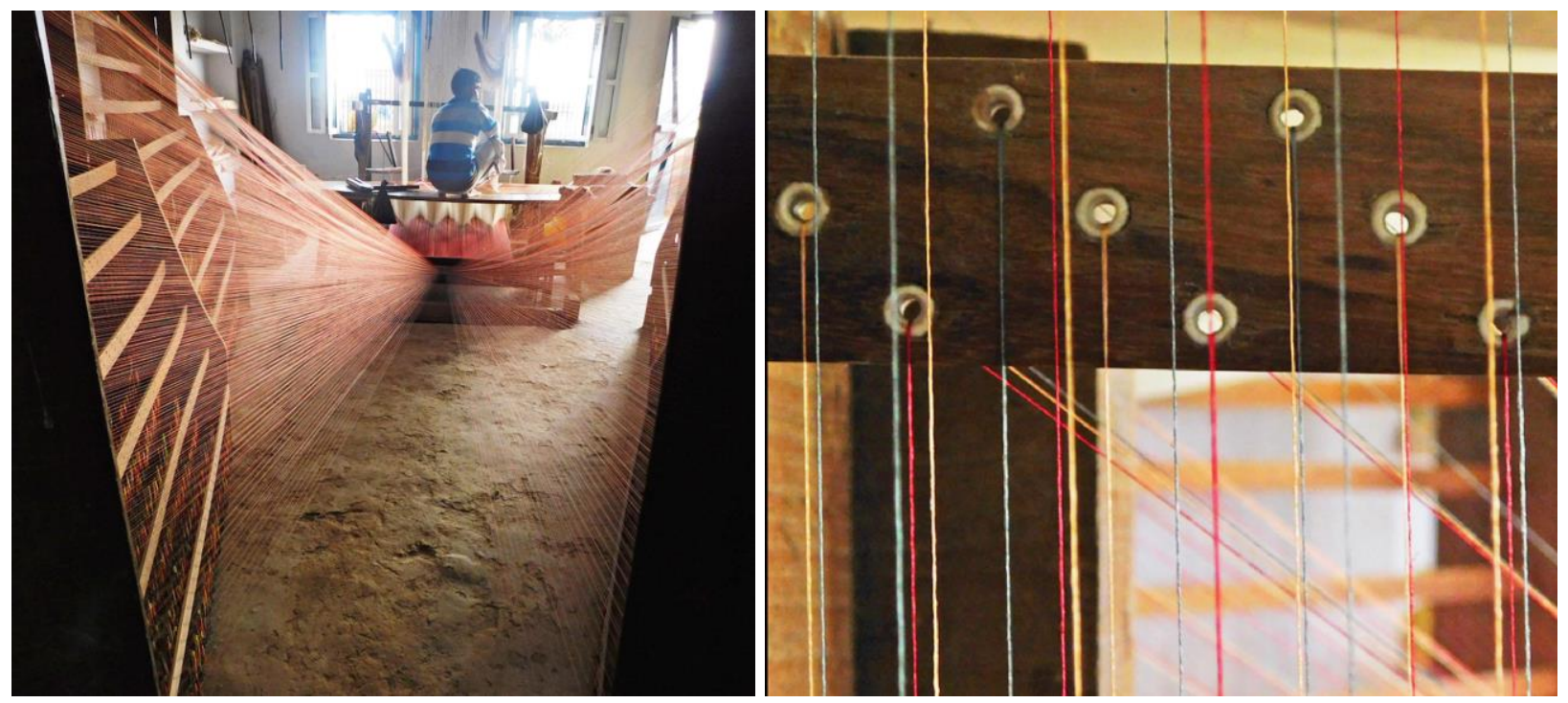

Fig. 50 The velvet bobbin rack with four banks of 35 slats. Fig. 51 Drilled holes for three colors of pile. Photos: Pickett, 2020

The textile terms I learned from the weavers derive from their local Hindi vernacular and stem from their Varanasi weaving tradition. Learning the common language of the atelier is extremely useful for me as an outsider, but also confusing. For example, the more colloquial term, jala, is often used instead of the more technically correct term, naqsha. The reed, the phanni, is the metal comb set in the beater that establishes the weaving width and organizes the density of the warps. The velvet on the loom used a reed with 40 dents per inch. Each dent, called a ghar, held three piles, one for each color, and five ground warps. It is 36 inches wide including the selvages made of six cords. 
Four artisans in steady, measured actions and unfaltering attention, coordinate to weave velvet. Shamim starts by inserting his raw razor blade into the miniscule channel on the first inserted velvet wire and drawing it carefully, cutting the pile loops and releasing the wire. The remaining two remaining wires keep the pile secure. Shamim's younger brother Belal, stationed on his board in back of the naqsha, pulls the kheva lash that selects the crosscords in the paggia. He inserts a large wooden fork, the mantha, twists it to clear and enlarge the shed. Shamim's wife Rijvana inserts a wooden hook, an ankda, on the left side and Shamim balances it with a matching hook on the right. She then clears the pattern shed with a rod so Shamim can enter the next velvet wire. He holds it firmly with the reed. He suppresses the treadle, making the shed for the first satin ground, throws his first water buffalo horn shuttle, a dharki, beats it in, and returns it for the second satin weft. On the third satin, he also raises all the pile for the crucial interlacement, followed by the fourth satin. Here is the trick that I failed to catch. Belal makes the shed for the first facing weft by pulling the necessary drawcord. Shamim throws his second shuttle with the facing weft, returns it for the second, and beats firmly. Belal gave me a big smile when I comprehended. This completes one round. It is important to note that both the satin and facing weft sequence are incomplete at this point and continue in order in the next round. The woven velvet cloth goes over a special front beam that is covered in material like a needle-board or card clothing that holds the tension. It proceeds down over two rollers before being loosely wound on a third beam, out of sight in the pit below. It takes approximately 34 rounds to weave one inch of velvet. A good day's work averages an inch or two. A full design repeat has almost 300 velvet wires.

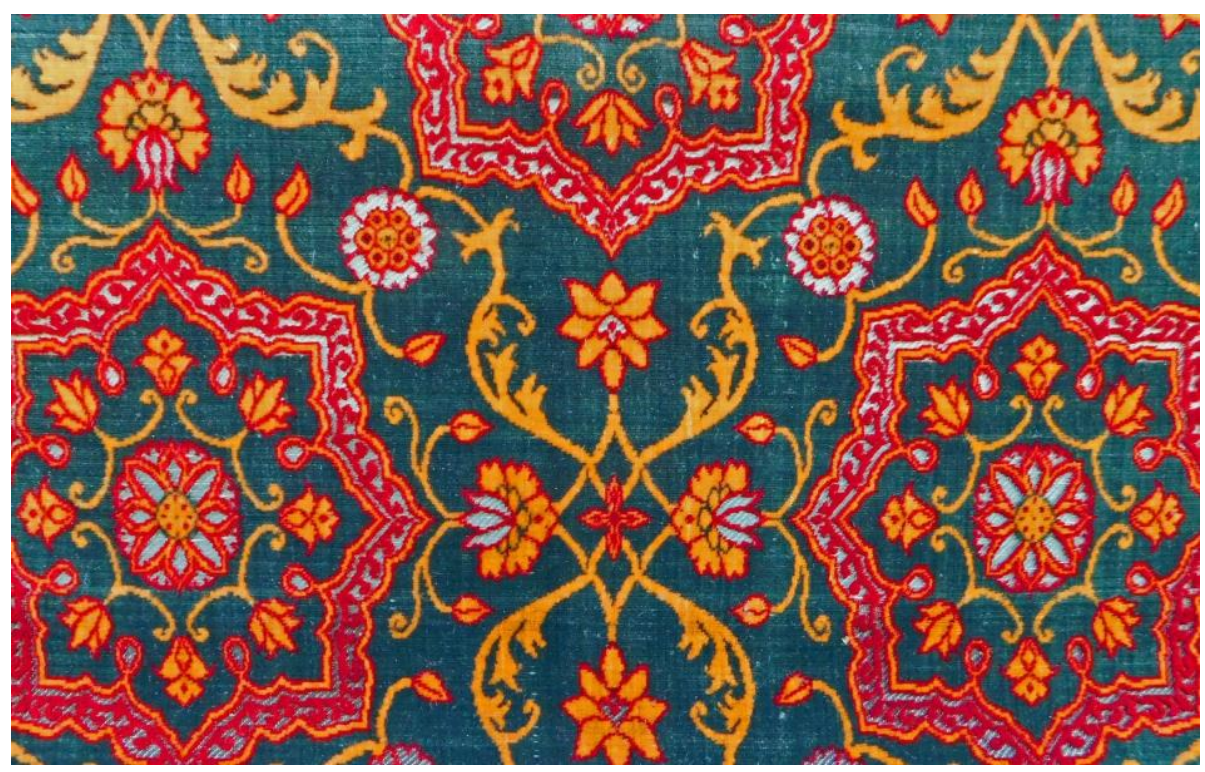

Fig. 52 Rahul Jain's velvet with three pile colors and blue facing weft. Photo: Pickett, 2021

The naqsha is customized for a specific design on a particular loom. Because this medallion has both a vertical and horizontal axis of reflection, the naqsha could have been built on a quadrant of the motif with the rest generated through the naka leashes and reversing the pulling order of the drawcords. Rahul described this design as a Safavid velvet with Mughal flavor. Cut pile almost completely covers the surface. Tiny voids show the sparkling blue facing weft like dew drops on a floral display (fig. 52). Rahul said that each project poses many solutions. He takes deep satisfaction when the choices minimize labor while heightening the artistry. Because this medallion was large and intricate, they decided to do two naqsha, which deftly decreased the number of 
paggia crosscords. In my opinion, the current literature lacks a definitive description of the naqsha design system with a full discussion of the possibilities considered by the naqshband .

Our five days together culminated with a feast at the Hotel Ganges View in the company of Rahul's inner circle of friends: Shashank Singh, the owner of the Hotel Ganges View and textile connoisseur; Shyam Sunder Jaiswal, who owns and runs the city's oldest and best-known gold and silver thread manufacturing workshop; Vinay Singh, a specialist in Persian and linguistics who has collaborated with Rahul on many projects; Sribhas Chandra Supakar, Varanasi's best-known designer of traditional textiles; and Anjan Chakraverty, Professor in the Department of Art History at Banaras Hindu University. The respect, admiration, and affection they have for each other was palpable. These comrades wanted to express their appreciation and gratitude to Carol for the book she edited, Woven from the Soul, Spun from the Heart (1987), and to Louise for her magnum opus, Symbols of Power (2015). Carol and Louise signed their books that so helped our Indian colleagues in their research. This returning refuels further research and connects us across time and space.

\section{Sustainability and Design Influences Annin Barrett}

Tracing the story of textile design migration and influence is a core part of my research, for historic examples as well as for understanding India's position in the world of modern and contemporary design. With this in mind, I will discuss two design colleges that we visited, Indian Institute of Crafts and Design (IICD), in Jaipur, as well as the National Institute of Design (NID), in Ahmedabad, and important exhibitions of Indian textiles by modern and contemporary artists in Jaipur and Ahmedabad. My focus is on examples of natural indigo dyeing, locally produced textiles with deep connections to place, and the practice of zero waste use of fabrics. These themes are key tenets of contemporary Western sustainable design, but are nothing new in India. The ongoing traditions and techniques passed down by generations of Indian textile makers have great currency today, especially in regard to sustainable design concepts and cultural decolonization.

Professor Sumita Choudhury invited us to IICD in Jaipur where my research colleagues and I were welcomed with a sumptuous faculty tea. We discussed sustainable fashion design curriculum and were given a tour of the textile classrooms. IICD hosted an international sustainable crafts design conference in 2017, with many papers about the timelessness of Indian textiles and their application to contemporary fashion, detailing how traditional natural dyes, zero waste patterning, and highly skilled surface design techniques all add value to garments. ${ }^{32}$ There is a growing awareness in India about its leadership role in educating the rest of the world about its venerable textile traditions and how these can help make sustainable fashion viable. With this exciting perspective, we were eager to tour the school and see new student work.

Faculty members showed us busy weaving studios and a courtyard craft market where students and traditional textile artisans from the community sell their handcrafted products, thereby informally learning from each other. We were struck by the respect given to textile knowledge, whether

32 Dr. Toolika Gupta, Prof. Bhargav Mistry, Dr. Barun Shankar Gupta, eds. A Treatise on Recent Trends and Sustainability in Crafts and Design, Indian Institute of Crafts \& Design, Jaipur (New Delhi: Excel India Publishers, 2017). Thanks to Barbara Setsu Pickett for this reference. 
academically credentialed or not. This valuing of traditional expertise is also evident at other Indian design colleges, especially NID, as I will discuss later in this paper.
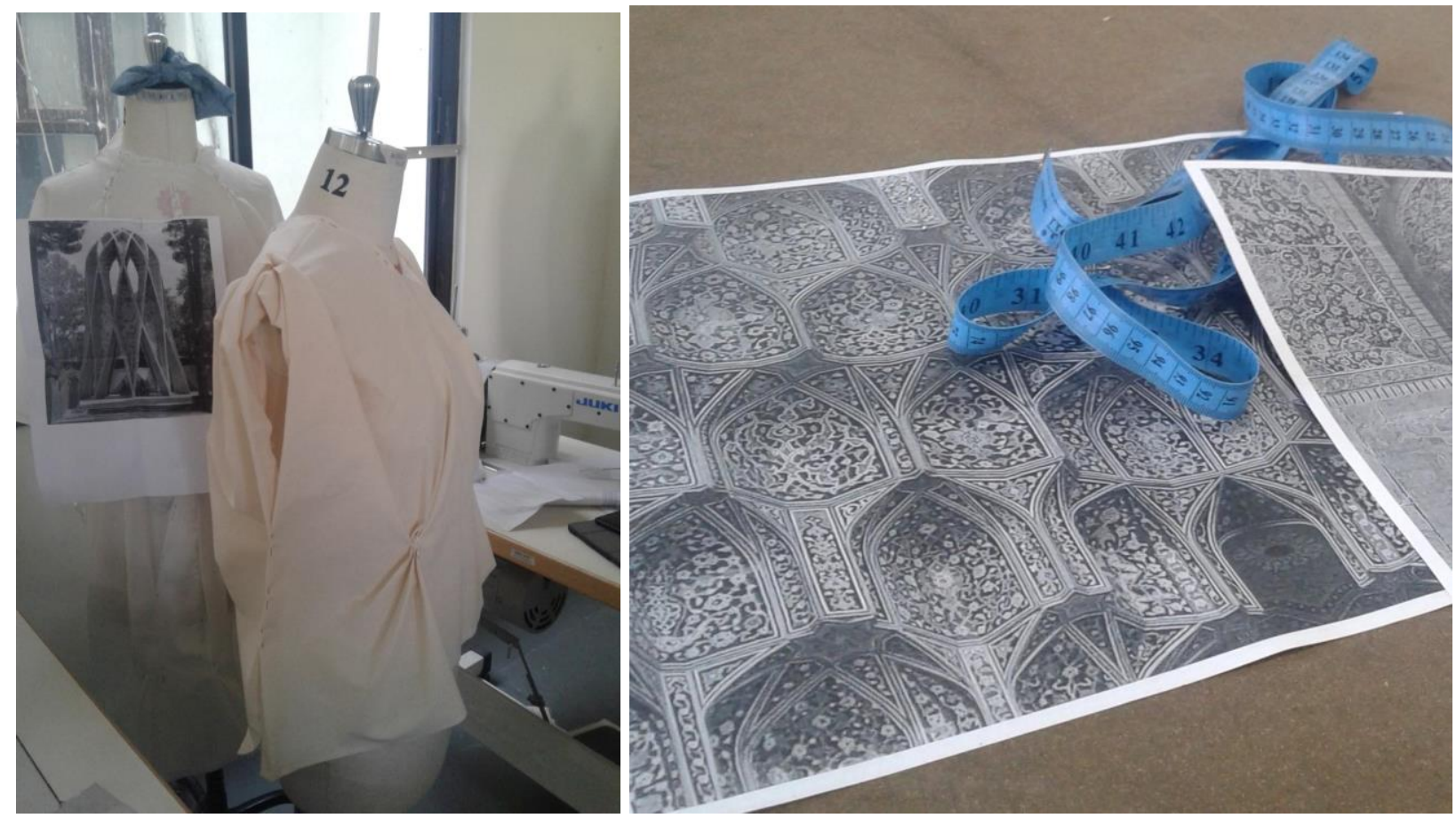

Fig. 53a-b Studio scenes from zero waste draping class inspired by Islamic architecture at Indian Institute of Crafts and Design, Jaipur. Photos: Annin Barrett, 2020

We had just visited great historic Indo-Iranian architectural sites in Delhi, Agra, and Fatehpur Sikri, led by Carol Bier to recognize their profound symmetrical and spatial relationships with textiles. So, we were pleased when Professor Anu Jain took us to a fashion draping class at IICD taught by Professor Mojgan Jahanara, visiting faculty from Iran, who used seventeenth-century Iranian architecture as design inspiration for students (fig. 53a-b). This confirmed our observations about the interplay of patterns between Mughal architecture and textiles, but in a contemporary fashion context. Students were challenged to make zero waste muslin garment samples by adapting shapes found in forts, mosques, and mausoleums using an entire piece of cloth. This lesson was even more impressive because of current political prejudice in India against its Mughal heritage.

India's eponymous and lucrative indigo crop figures prominently in Mughal Empire history. The ruler Akbar conquered Gujarat in 1573 for politically strategic reasons, and to control its indigo and cotton trade. This ancient dye and fiber are central to India's textile legacy. With that in mind, we visited Nila House (named after the Sanskrit word for blue), a new center in Jaipur for natural indigo dyeing and handcrafted textiles. Nila House opened in November 2019, founded by Lady Carole Bamford. This site is a beautiful 1940s residence, recently redesigned by renowned architect Binoy Jain using traditional building methods. ${ }^{33}$ The courtyard and textiles on display echoed the relationship we had seen between canopies and pavilions at historic sites such as Delhi's Red Fort, although on a smaller scale. Nila House curates gallery exhibits and workshops that bring together traditional Indian textile artists and designers dedicated to sustainable practices. Their inaugural

\footnotetext{
${ }^{33}$ https://www.architecturaldigest.in/content/jaipur-rajasthan-home-nila-house-bijoy-jain-interior-architechture/ (accessed 29 December 2020).
} 
exhibit, Revisiting Traditions: A showcase of artisanal fabrics from Kutch in Gujarat, successfully endeavored to celebrate the excellence of fabric-making as well as finished garments.

This show included textiles created with natural indigo by five artists, and a fashion collection by designer Ujjiwal Dubey made from handwoven fabrics by Khimji Kara Vankar. This exhibit highlighted the aesthetic value of the indigo-dyed textiles themselves, and the artists who made them (fig. 55). Technical Lead at Nila House, Juhi Pandey, coincidentally told us she had submitted an abstract for Textile Society of America's 2020 symposium about the changing social status of female weavers in Kutch (fig. 54). I was later thrilled to hear this paper, Reclaiming Traditions, that she virtually co-presented with textile artist Rajiben Vankar at this symposium. In an exemplary format that amplified instead of interpreted the voice of the artist, Rajiben Vankar explained her own sustainable art practice of weaving recycled plastics, and life experience. It was a powerful statement of personal agency and evolving social mores within a very traditional community known for its textile heritage.
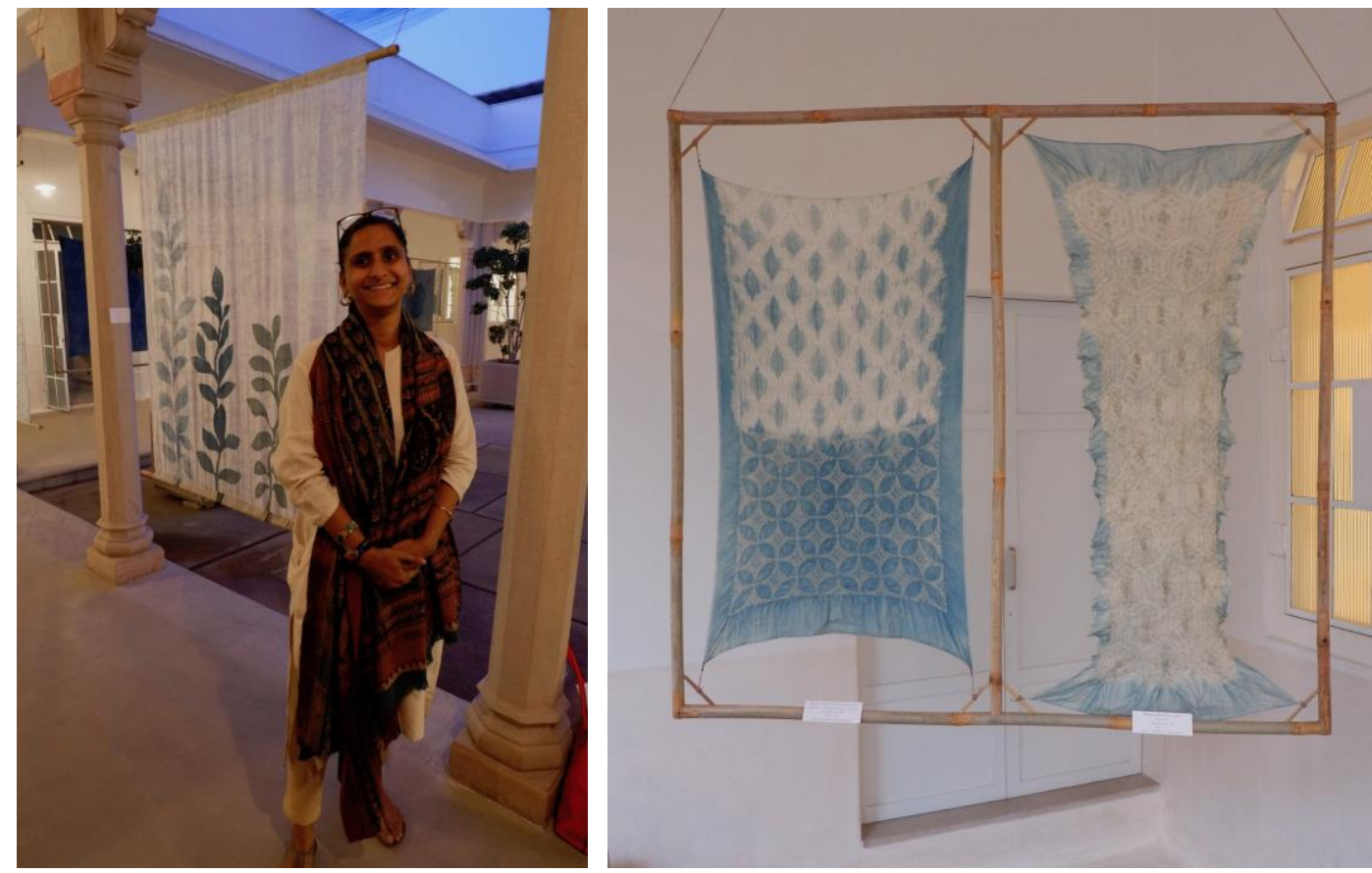

Fig. 54 Shakeel Ahmed Khatri, batik, with Technical Lead, Juhi Pandey, Fig. 55 Aziz Khatri, indigo dyed bandhani from Revisiting Traditions: A showcase of artisanal fabrics from Kutch in Gujarat, Nila House, Jaipur. Photos: Annin Barrett, 2020

Also in Jaipur, the Anokhi Museum of Hand Printing houses spectacular printed fabrics. This museum, with its excellent publications authored by curator Suki Skidmore, has exhibits of mordant resist and block printed textiles from Bagru and other nearby towns that explain their cultural context as an experience of local place. Certain print patterns traditionally denote social standing, such as being a widow, as well as identify the region where they are worn by their colors and motifs. In a new book and upcoming exhibit, block carvers from Farrukhabad tell their own story of their artform and the history of their city, another laudable example of artist amplification and self-representation. ${ }^{34}$

\footnotetext{
${ }^{34}$ Suki Skidmore, Farrukhabad: Art of the Block. Anokhi Museum of Hand Printing (Ahmedabad: AMHP Publications, 2020).
} 
Suki Skidmore invited us to visit the Anokhi apparel factory workrooms on the outskirts of Jaipur. We were welcomed there by the manager, who led us through the dyeworks, block printing studios, cutting rooms and sample library of this progressive company. We were impressed to learn that the Anokhi brand employs about 300 workers overall, including the outsourcing of some printing and dyeing from surrounding towns. Their apparel styles feature natural and low-toxin dyes and prints on cotton fabric, including indigo. Very aware of environmental problems with dye pollution, they recapture almost all dye and fabric finishing effluent in large tanks on site, filter and reuse it. We noticed how this collection method resonates with water canal systems from Mughal architecture, where clean water was a highly prized element of the garden as commemorated in rug designs shown in Louise Mackie and Anna Jolly's research (figs. 35, 37). In addition to caring for the environment, Anokhi is proud of having long-term employees and even provides childcare on-site for workers, achieving another goal of sustainable best practices.

Continuing our study of natural dyes, we attended a lecture on indigo by Michel Garcia and Yoshiko Wada produced by Ahmedabad's Trunk Textile Gallery at The House of MG Hotel. This fascinating lecture drew about 100 textile designers from NID and beyond for a riveting evening of discussion about the color blue. It was clear that Michel Garcia relished this opportunity to address textile experts and be able to talk about textile chemistry to a highly receptive audience. Afterward, Carol Bier met one of the attendees, designer Paresh Patel, who invited us to his studio outside of Ahmedabad in the village of Ridrol, Gujarat.

Paresh Patel is the founder of Royal Brocades, a weaving workshop that produces elegant silk ikats and also fabrics in the Ashavali brocade tradition that dates back hundreds of years. This style of weaving is thought to have begun in Gujarat and migrated to other Indian regions, such as Varanasi, after a huge fire in $1300 \mathrm{CE} .{ }^{35}$ On the wall of Paresh Patel's office in Ridrol, is a naqsha, the same coded string bundle we studied in Varanasi with Rahul Jain. Patel told us that his father had used the naqsha but they were replaced by Jacquard mechanisms in the 1980s. Today, dozens of looms at Patel's workshop are leased to local weavers, forming a small manufacturing hub. The coronavirus makes this a difficult time for everyone, but this workshop has withstood the challenges of the pandemic better than larger industrial textile mills and their mass layoff of workers. Patel mainly uses natural dyes, including indigo, for his textiles. He often posts his latest projects and opinions on Instagram, reaching an international audience.

Indigo dye is also the focus of the huge modern-day cotton denim corporation, Arvind, headquartered in Ahmedabad and helmed by members of the Lalbhai family. Although Arvind uses synthetic indigo now, on their website they promise the implementation of more sustainable practices in the near future. To that end, they have sponsored a museum dedicated to indigo at the Kasturbhai Lalbhai complex, part of the Lalbhai family's properties. Their premier exhibition, titled Alchemy, Explorations in Indigo, featured dozens of artists' works from all over the world in diverse media. Plaster, aluminum and many textiles continued the theme of architectural references we had encountered elsewhere with archways, stairs, walls and spatial settings, such as an installation of arches formed by the legs in dozens of jeans (fig. 56).

\footnotetext{
${ }^{35}$ Dr. Meenakshi Gupta and Vishu Arora, "Ashavali brocades from traditional to modern times," International Journal of Home Science 3 no. 2 (2017), 353-358.
} 


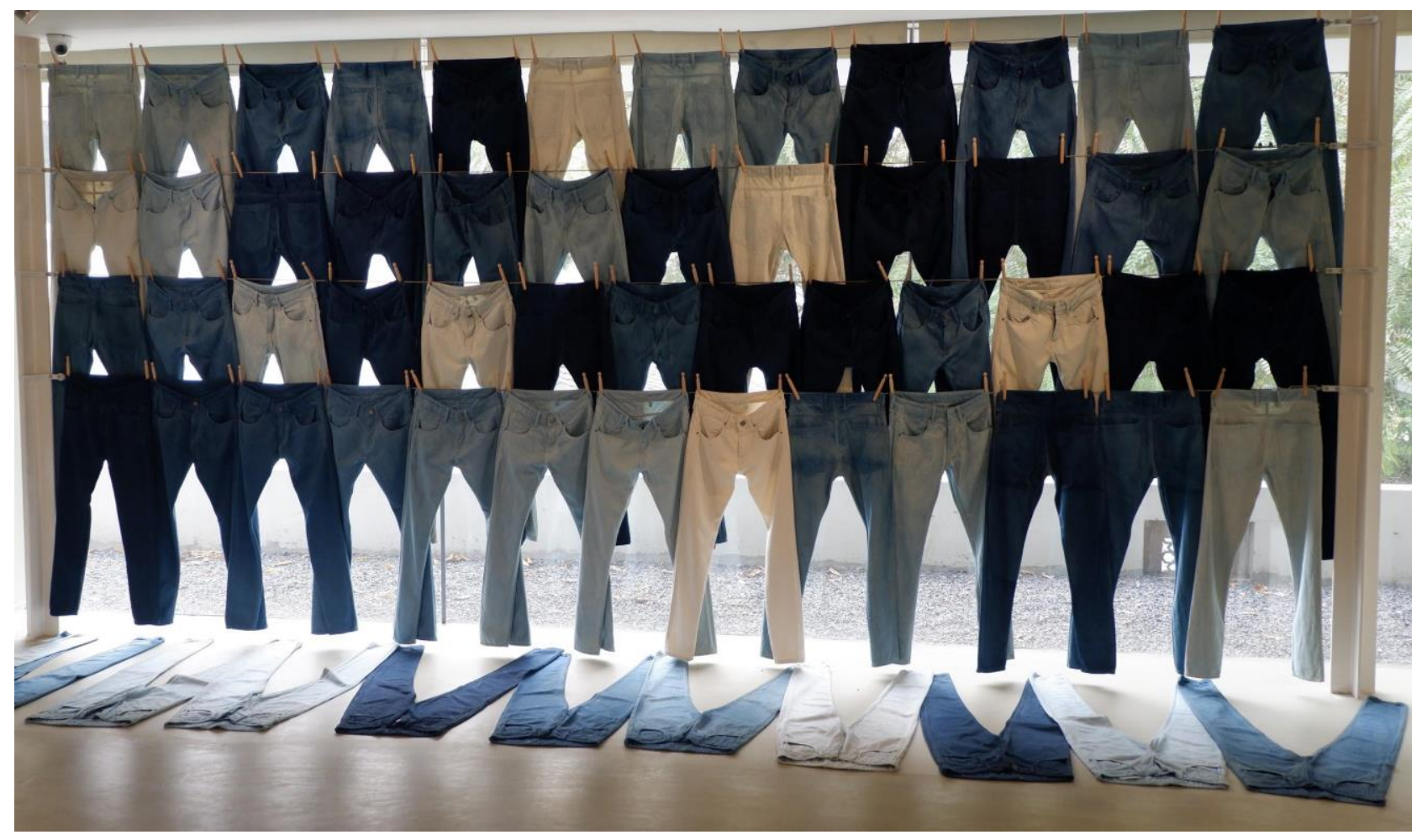

Fig. 56 Denim installation by Arvind Corporation at Alchemy, Explorations in Indigo exhibit, 2019, Kasturbhai Lalbhai Museum, Ahmedabad. Photo: Annin Barrett, 2020

In the same district of Ahmedabad, the famous Calico Museum, co-founded by Gira Sarabhai in 1949, fills a former home of the Sarabhai family. The Sarabhais, also wealthy owners of cotton mills, were involved with many twentieth century cultural projects, that included inviting modern designers like Charles and Ray Eames, Alexander Calder, Frank Lloyd Wright and Le Corbusier to come and work in India. The artist Frank Stella came and even designed calligraphic saris. Western Artists and India, a book edited by Shanay Jhaveri, describes a Sarabhai residency program that involved many modern designers and artists from the West. ${ }^{36}$ Charles and Ray Eames were commissioned by the Indian government to write The India Report, a 1958 document outlining a philosophy for training modern Indian designers based on respect for traditional craft processes as well as appreciation for indigenous Indian crafts makers. ${ }^{37}$ Modern influences from the Bauhaus and the Ulm School in Germany were favored by the Sarabhais, and guided by the Eames' proposal, this became the seed for the National Institute of Design (NID) in Ahmedabad.

One of Gira Sarabhai's many achievements was co-founding NID's textile program in 1969. When we visited in February 2020, textile arts faculty Swasti Singh Ghai and Shafique Afzal generously showed us the studio and took us to see the famous Pupul Jayakar volumes in the NID library. ${ }^{38}$

\footnotetext{
${ }^{36}$ I greatly appreciate Rahul Jain's knowledge about this topic, and his recommendation of the book: Shanay Jhaveri (editor), Western Artists and India (London: Thames and Hudson, 2013). The essay, "Charles and Ray Eames in India," by Saloni Mathur informed my thinking about postcolonial design influences between Indian and Western designers. ${ }^{37}$ Alternately titled “The Eames Report." Charles Eames and Ray Eames, "The Eames Report April 1958." Design Issues 7, no. 2 (1991): 63-75.

${ }^{38}$ The Jayakar Volumes: The Handloom Cottons of India, 1973-1983 (Development Commissioner for Handlooms, Government of India and the Handicrafts \& Handlooms Export Corporation of India, [s.1], 1985). As founder of the HHEC, Pupul Jayakar was a huge force in establishing postcolonial government support of Indian crafts.
} 
These seven large books holding thousands of handspun woven cotton fabric swatches, known as khadi, from everywhere in India are revered as a touchstone of national pride. They represent many different cotton varieties, and a wide selection of handspun cotton yarns and handwoven textures specific to regional places. Since Mahatma Gandhi, there has been a deep cultural connection with hand spinning cotton as an act of empowerment, and decolonization through local production, called swadeshi, that was quite prophetic in regard to sustainable fashion's principle of local supply chains. At Gandhi's ashram, also in Ahmedabad, spinning wheels represent the independence movement, the unbroken traditions of Indian craftspeople, and provide the source of inspiration for a sustainable future. Seeing all the Pupul Jayakar volumes' variations of indigenously grown, spun and woven cottons was thrilling, but Professor Afzal had another great experience for us, the $50^{\text {th }}$ anniversary exhibit of NID's textile program that he had co-curated.

At this on-campus exhibition, outstanding documentation of masters' theses on ikat, patola cloth, brocades and other artisanal textiles from all over India overwhelmed us. This respect given to traditional textile structures and design at the highest level of achievement is visionary. We also noted that sustainable textile practices, such as local supply chains and natural dyes, are repeatedly recognized at NID as a valuable part of India's textile heritage as well as its future. This impressive archived research is a foundation ready to inspire future generations of textile artists and designers.
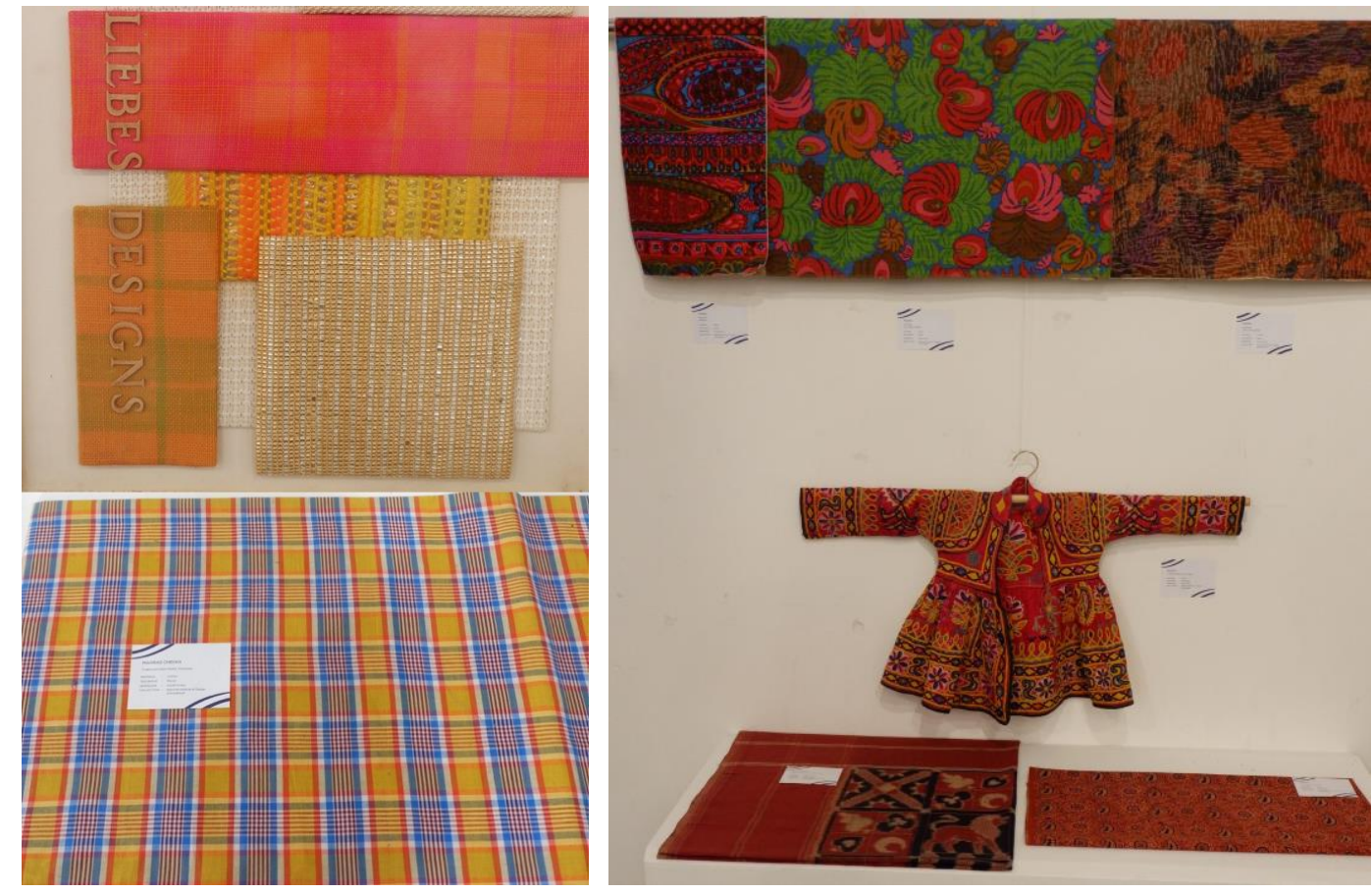

Fig. 57 Dorothy Liebes woven samples above Madras cotton plaid.

Fig. 58 Jack Lenor Larsen fabric print juxtaposed with katab appliqué jacket from Gujarat

50th Anniversary of National Institute of Design's Textile Program exhibit, Ahmedabad. Photos: Annin Barrett, 2020

In the exhibit were pieces by designers Dorothy Liebes and Jack Lenor Larsen, giving context to the school's early modernist influences. These fabrics created by Western designers showed undeniable influence from traditional Indian fabrics. Of course, influence rarely occurs in one direction only, and here were several examples of cultural appropriation embedded in well-known modernist textiles. Compare the colorways in cotton plaids typically worn as lunghis by Indian workers with Dorothy Liebes' wovens (fig. 57). Consider how a katab (appliqué) jacket from 
Gujarat would have informed Jack Lenor Larsen's design sensibility for his textile prints (fig. 58). Read M.P. Ranjan's book on bamboo and cane crafts to realize that woven bamboo and reed screens were traditional architectural textiles in Northeast India long before they became a staple of modernist domestic interiors in the West. ${ }^{39}$ Modern design may have begun at the Bauhaus in Germany and developed in Europe and America, but its textiles, art and architecture were clearly inspired and nurtured by India. There is a vast amount of research still to do on India's profound influence on Western design history, so far mostly uncredited.

In the field of sustainable design, textile design practices that have stood the test of time deserve closer consideration, and India is wealthy in textile experience. From empire to colonialism to independence to globalization, textiles have played a crucial role in every stage of India's history. There is a lot to learn from the deep connection between fabrics and specific places, and how they affect a culture that has never lost this link. India is at the forefront of a growing awareness of the importance of sustainable textiles that are locally produced with natural materials, and remains a source of encyclopedic textile knowledge for future research and practice.

\section{Reflections on Our Team Approach to Field Research}

Like a wide-array telescope, our traveling seminar gathered information and insights. Thankfully we returned just before the coronavirus pandemic hit. We met weekly through Zoom to prepare our online roundtable and write our joint article. Our frequent post-trip discussions broadened understanding, clarified thoughts, and cemented friendships.

We recommend comparable, collaborative field research, especially for subjects with related specialties, much as Rahul Jain's drawlooms served as a focus for us. It would be good if the historical textile collections in India could be included more actively in global textile research and if cooperation among Indian and Western museums could thus be strengthened. We would surely all benefit from a more lively exchange and shared experience. We encourage TSA to promote more roundtables and to advocate for team approaches to research.

Our team would like to extend heartfelt thanks to Rahul Jain, and to all the skilled artisans, small business owners, and curators, who demonstrated their skills and showed us their specialties, plus our guides, drivers and so many more in India. We wish them and their families good health and well-being during the Covid-19 pandemic and in the future.

${ }^{39}$ M.P. Ranjan, N. Iyer, and G. Pandya, Bamboo and Cane Crafts of Northeast India. (Ahmedabad: National Institute of Design, 1986). 
$\underline{\text { Bibliography }}$

Allāmī, Abu'1 Fazl. The Ā'ìn-i Akbarī. Vol 1. Calcutta: [Royal] Asiatic Society of Bengal, 1939, 93-94.

Andrews, Peter A. Felt Tents and Pavilions: The Nomadic Tradition and Its Interaction with Princely Tentage. London: Melisende, 1999.

Andrews, Peter A. and Mugul Andrews. Tentage at the Calico Museum and Its Patterns. Ahmedabad: Sarabhai Foundation, 2015.

Atasoy, Nurhan, Walter B. Denny, Louise W. Mackie, and Hülya Tezcan. IPEK: Imperial Ottoman Silks and Velvets, eds. Julian Raby and Alison Effeny. London: Azimuth Editions on behalf of TEB Iletisim ve Yayınc1lı, 2001.

Bier, Carol. The Persian Velvets at Rosenborg. Copenhagen: Rosenborg and Dadema Trading, 1995.

Bier, Carol, ed. Woven from the Soul, Spun from the Heart: Textile Arts of Safavid and Qajar Iran 16th-19th Centuries. The Textile Museum, 1987.

Bier, Carol and Dave Masunaga, "Textiles - Math = 0; Textiles + Math = Infinity," plenary session (unpublished), Textile Narratives \& Conversions: Proceedings of the 10th Biennial Symposium of the Textile Society of America. Presented in Toronto, ON, Canada, October 11-14, 2004. https://digitalcommons.unl.edu/cgi/viewcontent.cgi? article=1365\&context=tsaconf (accessed 27 July 2021).

Chowdhury, Zirwat. "An Imperial Mughal Tent and Mobile Sovereignty in Eighteenth-Century Jodhpur," Art History (4 September 2015): 668-681. DOI: 10.1111/1467-8365.12174 (accessed 3 January 2021).

Collingwood, Peter. The Techniques of Split-Ply Braiding. Petaluma, CA: Unicorn Books, 1998.

Dhamija, Jasleen. Gourmet's Journey: Discovering the Exotic \& Erotic in Food. New Delhi: Women Unlimited, 2018.

Dhamija, Jasleen. Living Traditions of Iran's Crafts. New Delhi: Vikas, c1979.

Dhamija, Jasleen, contributing author. Baluchari: Bengal and Beyond. Kolkata: Weavers Studio Resource Centre, 2016. 
Dhamija, Jasleen, ed. The Woven Silks of India. Mumbai: Marg Publications, 1995.

Dhamija, Jasleen, ed. Crafts of Gujarat. [Ahmedabad] New York: Mapin, 1985.

Dhamija, Jasleen and Jyotindra Jain, eds. Handwoven Fabrics of India. Ahmedabad: Mapin, 1989.

Eames, Charles and Ray Eames. "The Eames Report April 1958," Design Issues 7/2 (1991), 63-75.

Golombek, Lisa and Ebba Koch. "The Mughals, Uzbeks, and the Timurid Legacy," in A Companion to Islamic Art and Architecture. Eds., F. B. Flood and G. Necipoğlu. Hoboken NJ: John Wiley \& Sons, 2017.

Gupta, Meenakshi and Vishu Arora. "Ashavali brocades from traditional to modern times," International Journal of Home Science 3/2 (2017), 353-358.

Gupta, Toolika, Bhargav Mistry, and Barun Shankar Gupta, eds. A Treatise on Recent Trends and Sustainability in Crafts and Design. Indian Institute of Crafts \& Design, Jaipur. New Delhi: Excel India Publishers, 2017.

Healy, Bruce. “The Jaipur Garden Carpet,” Hali (March 30, 2020), https://hali.com/articles/thejaipur-garden-carpet/ (accessed 3 January 2021).

Jain, Binoy. "Jaipur: Inside the coveted Nila House, a home turned into a craftsmanship centre," Architecture \& Design (October 17, 2019), https://www.architecturaldigest.in/content/jaipurrajasthan-home-nila-house-bijoy-jain-interior-architechture/ (accessed 28 July 2021).

Jain, Rahul. Indian Lampas Weave Silks in the Collection of the Calico Museum of Textiles. Woven Textiles. Technical Studies Monograph 3. Ahmedabad: Sarabhai Foundation, 2013.

Jain, Rahul. Rapture: The Art of Indian Textiles. New Delhi: Niyogi Books, 2011.

Jain, Rahul. Mughal Velvets in the Collection of the Calico Museum of Textiles. Woven Textiles. Technical Studies Monograph 2. Ahmedabad: Sarabhai Foundation, 2011.

Jain, Rahul. Mīnākār. Spun Gold and Woven Enamel. New Delhi: Textile Art, 1997. 
Jain, Rahul. "The Indian Drawloom and its Products," The Textile Museum Journal 32-33 (19931994), 50-81.

Jhaveri, Shanay, ed. Western Artists and India. London: Thames and Hudson, 2013.

Koch, Ebba. The Complete Taj Mahal and the Riverfront Gardens of Agra. London: Thames \& Hudson, 2006.

Mackie, Louise W. Symbols of Power: Luxury Textiles from Islamic Lands, 7th-21st Century. The Cleveland Museum of Art, New Haven and London: Yale University Press, 2015.

Mackie, Louise W. "Increase the Prestige: Islamic Textiles," Arts of Asia 26/1 (1996), 82-93.

"Pra-Kashi: Silk, Gold and Silver from the City of Light," ASHA 25th Anniversary Exhibition, National Museum, New Delhi, 2019.

Mathur, Saloni. "Charles and Ray Eames in India," in Shanay Jhaveri, ed. Western Artists and India (London: Thames and Hudson, 2013), 82-97.

Pickett, Barbara Setsu. "Rahul Jain's Reimagined Indian Velvet Drawloom.," published in The Social Fabric: Deep Local to Pan Global; Proceedings of the Textile Society of America 16th Biennial Symposium. Presented at Vancouver, BC, Canada; September 19 - 23, 2018.

https://digitalcommons.unl.edu/tsaconf/ DOI 10.32873/unl.dc.tsasp.0045 (accessed 27 July 2021).

Ranjan, M. P., N. Iyer, and G. Pandya, Bamboo and Cane Crafts of Northeast India. Ahmedabad: National Institute of Design, 1986.

Sadaf, Fatma. "Gardens in Mughal India in the Light of Inscriptions," Proceedings of the Indian History Congress 74 (2013), 297-98 http://www.jstor.org/stable/44158828 (accessed 14 January 2021).

Sahay, Binoy Kumar. "Technical Studies of Central Asian Textiles," in B. R. Mani and Anamika Pathak, eds. Textiles: Binding Thread between Cultures from National Museum Collections. New Delhi: National Museum, 2019, 74-91.

Singh, Martand and Jyotindra Jain, eds. The Jayakar Volumes: The Handloom Cottons of India, 1973-1983. Development Commissioner for Handlooms, Government of India and the Handicrafts \& Handlooms Export Corporation of India, [s.1.], 1985. 
Skidmore, Suki. Farrukhabad: Art of the Block. Ahmedabad: Anokhi Museum of Hand Printing Publications, 2020.

Sonday, Milton and Nobuko Kajitani. "A Type of Mughal Sash,” Textile Museum Journal 3/1 (1970), 45-54.

Sonday, Milton and Nobuko Kajitani, “A Second Type of Mughal Sash,” Textile Museum Journal 3/2 (1971), 6-12.

Tavernier, Jean-Baptiste. Travels in India by Jean-Baptiste Tavernier. Ttr. V. Ball. London, New York: Macmillan, 1889.

Walker, Daniel S. Flowers Underfoot: Indian Carpets of the Mughal Era. New York: The Metropolitan Museum of Art, 1997. 